\title{
Biological Effect of Silver-modified Nanostructured Titanium Dioxide in Cancer
}

\author{
NEFELI LAGOPATI ${ }^{1,2,3^{*}}$, ATHANASSIOS KOTSINAS ${ }^{1 *}$, DIMITRIS VEROUTIS ${ }^{1,3}$, KONSTANTINOS EVANGELOU $^{1}$, \\ ANGELOS PAPASPYROPOULOS ${ }^{1,3}$, MICHALIS ARFANIS ${ }^{4}$, POLYCARPOS FALARAS ${ }^{4}$, PARASKEVI V. KITSIOU ${ }^{5}$, \\ IOANNIS PATERAS ${ }^{1}$, ANNA BERGONZINI $^{6}$, TERESA FRISAN $^{6}$, SPYRIDON KYRIAZIS $^{1}$, \\ DIMITRIOS S. TSOUKLERIS ${ }^{2,7}$, EFFIE-PHOTINI C. TSILIBARY ${ }^{8}$, MARIA GAZOULI $^{9}$, \\ EVANGELIA A. PAVLATOU ${ }^{2}$ and VASSILIS G. GORGOULIS ${ }^{1,3,10,11}$ \\ ${ }^{1}$ Laboratory of Histology-Embryology, Molecular Carcinogenesis Group, \\ Medical School, National and Kapodistrian University of Athens, Athens, Greece; \\ ${ }^{2}$ Laboratory of General Chemistry, School of Chemical Engineering, \\ National Technical University of Athens, Zografou Campus, Athens, Greece; \\ ${ }^{3}$ Biomedical Research Foundation Academy of Athens, Athens, Greece; \\ ${ }^{4}$ Institute of Nanoscience and Nanotechnology, Laboratory of Nanotechnology Processes for Solar Energy \\ Conversion and Environmental Protection, National Centre for Scientific Research "Demokritos", Athens, Greece; \\ ${ }^{5}$ Institute of Biosciences and Applications, Laboratory of Biochemistry/Cell \& Matrix Pathobiology, \\ National Centre for Scientific Research "Demokritos", Athens, Greece; \\ ${ }^{6}$ Umeå Centre for Microbial Research (UCMR), Department of Molecular Biology, Umeå University, Umeå, Sweden; \\ ${ }^{7}$ NanoViis Company, Athens, Greece; \\ ${ }^{8}$ Department of Neuroscience, University of Minnesota, Minneapolis, MN, U.S.A.; \\ ${ }^{9}$ Department of Basic Medical Sciences, Laboratory of Biology, Faculty of Medicine, School of Health Science, \\ National and Kapodistrian University of Athens, Athens, Greece; \\ ${ }^{10}$ Faculty of Biology, Medicine and Health Manchester Cancer Research Centre, \\ Manchester Academic Health Sciences Centre, University of Manchester, Manchester, U.K.; \\ ${ }^{11}$ Center for New Biotechnologies and Precision Medicine, Medical School, \\ National and Kapodistrian University of Athens, Athens, Greece
}

\begin{abstract}
Background/Aim: Nanomedicine is a promising scientific field that exploits the unique properties of innovative nanomaterials, providing alternative solutions in
\end{abstract}

This article is freely accessible online.

*These Authors contributed equally to this work.

Correspondence to: Prof. Vassilis G. Gorgoulis, Laboratory of Histology-Embryology, Molecular Carcinogenesis Group, Medical School, National and Kapodistrian University of Athens, 75 Mikras Asias Str., Goudi, GR 11527, Athens, Greece. Tel: +30 2107462352, e-mail: vgorg@med.uoa.gr; Prof. Evangelia A. Pavlatou, Laboratory of General Chemistry, School of Chemical Engineering, National Technical University of Athens, 9 Iroon Politechniou Str., GR 15780, Zografou Campus, Athens, Greece. Tel: +30 2107723110, e-mail: pavlatou@chemeng.ntua.gr

Key Words: Nanomedicine, nanostructured titanium dioxide, silvermodified titanium dioxide, photocatalysis, cytotoxicity, apoptosis, anticancer properties. diagnostics, prevention and therapeutics. Titanium dioxide nanoparticles $\left(\mathrm{TiO}_{2} \mathrm{NPS}\right)$ have a great spectrum of photocatalytic antibacterial and anticancer applications. The chemical modification of $\mathrm{TiO}_{2}$ optimizes its bioactive performance. The aim of this study was the development of silver modified NPs ( $\left.\mathrm{Ag} / \mathrm{TiO}_{2} \mathrm{NPS}\right)$ with anticancer potential. Materials and Methods: $\mathrm{Ag} / \mathrm{TiO}_{2} \mathrm{NPs}$ were prepared through the sol-gel method, were fully characterized and were tested on cultured breast cancer epithelial cells (MCF-7 and MDAMB-231). The MTT colorimetric assay was used to estimate cellular viability. Western blot analysis of protein expression along with a DNA-laddering assay were employed for apoptosis detection. Results and Conclusion: We show that photo-activated $\mathrm{Ag}_{\mathrm{TiO}} \mathrm{NPS}_{2}$ exhibited significant cytotoxicity on the highly malignant MDA-MB-231 cancer cells, inducing apoptosis, while MCF-7 cells that are characterized by low invasive properties were unaffected under the same conditions.

Nanomedicine is an emerging inter-disciplinary scientific field that exploits the unique properties of innovative 
nanomaterials, providing alternative solutions in diagnostics, prevention and therapeutics (1). In this framework, nanostructured titanium dioxide $\left(\mathrm{TiO}_{2}\right)$ has been thoroughly studied. The physical and chemical stability of $\mathrm{TiO}_{2}$, high semi-conducting catalytic activity, interesting optoelectronic properties, low cost (2), high oxidative activity and relative ease of production are the main characteristics of this nanomaterial and for these reasons its potential has been exploited in various applications. Nowadays, since the pandemic emerged, a large number of masks and uniforms require sterilization more than ever before. Thus, photocatalysts, such as $\mathrm{TiO}_{2}$ are promising candidates to provide protection even against SARS-CoV-2, offering bactericidal and virucidal activity. Due to the biocompatibility and the great spectrum of anticancer and antimicrobial properties, $\mathrm{TiO}_{2}$ is utilized in various biomedical applications, such as in drug delivery systems (DDS), in molecular imaging as well as in alternative therapeutic approaches, in parallel with conventional methods or in replacement of them $(3,4)$.

$\mathrm{TiO}_{2}$ can cause cytotoxicity (5) and induce apoptosis (6, 7). Various studies indicate that $\mathrm{TiO}_{2}$ nanoparticles (NPs) can interfere through EGFR signaling pathways (8), leading to the inhibition of cell proliferation and survival, inducing senescence or apoptosis. During the early stages of cancer, senescence can act as an additional anti-cancer barrier, by inhibiting the propagation of incipient cancer cells, as apoptosis does (9). Intriguingly, senescence is also characterized by tumor promoting properties through a related secretory activity termed senescence associated secretory phenotype (SASP) (9). In this context, innovative alternative theranostics based on nanomedicine might focus on targeting of senescent cells (10).

The uptake of $\mathrm{TiO}_{2}$ NPs in the cells, perhaps, can be achieved through endocytosis and passive diffusion. Since $\mathrm{TiO}_{2}$ NPs behave as photocatalysts, when they are excited by photon energy derived from ultraviolet light (UV-A), pairs of holes and electrons are generated, reacting with the available water and oxygen, yielding reactive oxygen species (ROS) (11). This phenomenon can take place when $\mathrm{TiO}_{2}$ NPs enter the cell and since the produced free radicals might be potentially very harmful (12), $\mathrm{TiO}_{2}$ NPs may prove efficient damaging agents against crucial biomolecules of cancer cells. If this event is triggered controllably, it can specifically target the cancer cells, sparing the healthy ones. Such a scenario may be considered as the basis for the design and development of alternative therapeutic approaches.

The photocatalytic properties can be improved by several strategies. Chemical modification, dye-sensitization and coupling are among the most common techniques that are used for intervening in the properties of synthesized materials. Each of these methods is characterized by specific advantages and disadvantages (13). Chemical modification with metals or non-metals governs the physical-chemical properties of $\mathrm{TiO}_{2}$, optimizing its photocatalytic and bioactive performance (14). Silver is used as a dopant, since it has the ability to trap the photo-excited electrons from $\mathrm{TiO}_{2}$, allowing to the holes remain active (15). Thus, surface modification with silver reduces the recombination between the short-lived photoelectrons of the conduction band and the positive holes of the semiconductor band. Furthermore, silver particles have the ability to facilitate the electron excitation, since they can generate a local electric field (16). This field can be reasonably enhanced by the plasmon resonance effect due to the presence of the silver particles. According to many studies, chemical modification with silver increases the Specific Surface Area (SSA) of the $\mathrm{TiO}_{2}$, improving its photocatalytic activity (17). In fact, silver modification promotes the ROS generation (18) prolonging the bioactivity duration of the $\mathrm{TiO}_{2}$ NPs.

The aim of this study was the development of silvermodified $\mathrm{TiO}_{2}$ NPs $\left(\mathrm{Ag} / \mathrm{TiO}_{2} \mathrm{NPs}\right)$ with anticancer potential upon photoexcitation. The cytotoxic effects of $\mathrm{Ag} / \mathrm{TiO}_{2} \mathrm{NPs}$ were examined on two cancer cell lines, derived from breast epithelium: a) MDA-MB-231 (human breast adenocarcinoma, highly invasive) and b) Michigan Cancer Foundation (MCF)7 (low metastatic potential). Consequently, the cytotoxicity mechanisms induced by $\mathrm{Ag} / \mathrm{TiO}_{2}$ NPs were investigated, showing that $\mathrm{Ag} / \mathrm{TiO}_{2} \mathrm{NPs}$ led to significantly higher cytotoxicity a significant the malignant MDA-MB-231 cancer cells, inducing apoptosis upon irradiation with UV-A light, while MCF-7 cells were not considerably affected.

\section{Materials and Methods}

Preparation of $\mathrm{Ag} / \mathrm{TiO}_{2} \mathrm{NPs}$. $\mathrm{Ag} / \mathrm{TiO}_{2} \mathrm{NPs}$ were prepared through the sol-gel technique. Titanium (IV) butoxide $(20 \mathrm{ml})$ was added in acidified aquatic solution under vigorous stirring. Then $30 \mathrm{ml}$ of 1butanol were added, leading to the formation of a clear sol-gel. An amount of silver nitrate $\left(\mathrm{AgNO}_{3}\right.$, Sigma-Aldrich, Darmstadt, Germany) was dissolved into deionized water and a final $\mathrm{AgNO}_{3}$ solution of $0.75 \% \mathrm{w} / \mathrm{v}$ was obtained. Stirring for $24 \mathrm{~h}$ at room temperature (RT) followed. The pre-synthesized suspension was transferred into a stainless-steel chamber (autoclave) lined with Teflon material and was treated at $100^{\circ} \mathrm{C}$ for $12 \mathrm{~h}$, via the hydrothermal process. The precipitates were allowed to dry at $400^{\circ} \mathrm{C}$ for $6 \mathrm{~h}$ and were purified, resulting in the production of $\mathrm{Ag} / \mathrm{TiO}_{2}$ NPs (19). The whole procedure was implemented in the dark.

Characterization of $\mathrm{Ag} / \mathrm{TiO}_{2} \mathrm{NPs}$. The synthesized nanopowders were characterized with respect to powder size, morphology, zeta-potential and bandgap. For this reason, X-ray diffraction (XRD), micro-Raman Spectroscopy, Infrared Spectroscopy, UV-Vis Spectroscopy, field emission gun scanning electron microscope, X-ray photoelectron spectroscopy and dynamic light scattering were employed.

The crystal phase determination and the crystallite size estimation of the $\mathrm{Ag} / \mathrm{TiO}_{2} \mathrm{NPs}$ were carried out through the XRD method. X-ray diffraction analysis was held at a Siemens D-5000 diffractometer, operating at $40 \mathrm{kV}$ and $35 \mathrm{~mA}$ with a $\mathrm{Cu}-\mathrm{K}_{\alpha}$ 
radiation $\lambda$ of $1.54 \AA$. The measurements were held at a 2-theta angle, a range between $20^{\circ}$ and $80^{\circ}$ and a scanning rate $0.1^{\circ} / \mathrm{min}$.

The surface topography of the $\mathrm{Ag} / \mathrm{TiO}_{2} \mathrm{NPs}$ was studied by a field emission gun scanning electron microscope (FEG-SEM, FEI Quanta 200F, FEI Company, Hillsboro, OR, USA). Prior to FEG-SEM investigations, $1 \mathrm{mg}$ of powder were placed at the carbon tape and evaporated by gold to ensure conductivity.

Raman spectroscopy was applied to clarify the complexity of the structure of the produced $\mathrm{Ag} / \mathrm{TiO}_{2} \mathrm{NPs}$. The Raman device used was the inVia model from Renishaw (inVia, Renishaw, Wotton-underEdge, Gloucestershire, UK). For measurement needs, a high power near infrared (NIR) diode laser $(\lambda=785 \mathrm{~nm})$ and a solid-state laser $(\lambda=532 \mathrm{~nm}$ ) were used as excitation sources, at RT in backscattering configuration. To avoid local heating and phase transformation, a $\times 100$ short distance magnification lens, of low excitation power guided the laser beam, focusing onto the samples. The calibration of the frequency shifts was achieved through an internal $\mathrm{Si}$ reference. 3-4 spots were taken for each sample, with an exposure time of $30 \mathrm{~s}$ and 2-10 accumulations.

The surface chemical states of the $\mathrm{Ag} / \mathrm{TiO}_{2} \mathrm{NPs}$ were analyzed by X-ray photoelectron spectroscopy (XPS-Particle size analyzer, Thermo K-Alpha). An ultra-high vacuum system (UHV), with base pressure $1 \times 10^{-9}$ mbar, equipped with a monochromatic AlK $\alpha$ line at $1,486.6 \mathrm{eV}$ was used for the photoemission experiments. A fitting routine was utilized for the XPS core level spectra analysis. This routine allowed the decomposition, of each spectrum into individual mixed Gaussian-Lorentzian peaks after a Shirley background subtraction. The powder-like samples had to be pressed in stainless steel pellets before the measurement. Survey spectra were acquired with a pass energy of $200 \mathrm{eV}$ and a total of 10 scans with an energy step size of $1 \mathrm{eV}$. Valence band spectra were acquired using a pass energy of $50 \mathrm{eV}$ and a total of 20 scans with an $0.1 \mathrm{eV}$ energy step. High resolution scans of relevant elements were acquired with a pass energy of $50 \mathrm{eV}$ and a total of 10 scans with an energy step size of $0.1 \mathrm{eV}$.

A UV-Vis spectrometer (U-3010, Hitachi, Tokyo, Japan) with an integrating sphere $(50 \mathrm{~mm})$ that allows diffuse reflectance measurements was used for the determination of the band gap $\left(\mathrm{E}_{\mathrm{g}}\right)$ of the $\mathrm{Ag} / \mathrm{TiO}_{2}$ NPs. The light source was a deuterium lamp (DH2000), providing the light in the range of $210 \mathrm{~nm}-1000 \mathrm{~nm}$.

Finally, the size estimation and the zeta-potential of the $\mathrm{Ag} / \mathrm{TiO}_{2}$ NPs were determined via dynamic light scattering (DLS) by utilizing Zeta Sizer nano S (Malvern Inst., Malvern, UK). The average distribution of the NPs was estimated in aqueous dispersions, measured at different $\mathrm{pH}$ values (from 2 to 8 ) as it had been described previously in Lagopati et al. (6).

Cell culture. Two different cancer cell lines [MDA-MB-231 (human breast adenocarcinoma, highly invasive, ATCC - LGC Standards GmbH, Wesel, Germany) and Michigan Cancer Foundation MCF-7 (low metastatic potential, ATCC - LGC Standards GmbH)], both derived from breast epithelium, were used for the need of the experiments, focusing on the anticancer effect of $\mathrm{Ag} / \mathrm{TiO}_{2} \mathrm{NPs}$. The cells were cultured in $75 \mathrm{~cm}^{2}$ flasks or petri dishes, in Dulbecco's modified Eagle's medium (DMEM) that was supplemented with $10 \%$ fetal bovine serum (FBS), $1 \%$ sodium pyruvate, $1 \% \mathrm{~L}-$ glutamine, and antibiotics (BioWest, Nuaillé, France); They were incubated at $37^{\circ} \mathrm{C}$ in a $5 \% \mathrm{CO}_{2}$ incubator. Moreover, trypsin-EDTA: $0.05 \% / 0.02 \%$ (w/v) (Gibco BRL, Life Technologies, Thermo Scientific, Paisley, UK) was utilized for the collection of cells (7).
Effect on cell proliferation. A cell population of about 100,000 cells/well was cultured in 6-well plates, in order to investigate the effect of the $\mathrm{Ag} / \mathrm{TiO}_{2} \mathrm{NPs}$ on proliferation. Increasing concentrations of $\mathrm{Ag} / \mathrm{TiO}_{2} \mathrm{NPs}$ dispersions were added to the appropriate plates, 24 $\mathrm{h}$ after plating. The samples were irradiated for $10 \mathrm{~min}$, using four parallel UV-A light lamps (wavelength $350 \mathrm{~nm}, 3 \mathrm{~mW} \mathrm{~cm}-2$, Sylvania, OH, USA), into a lab-made photoreactor.

To avoid thermal effects, due to the possible temperature increase, a venting system was incorporated into the photoreactor and the samples were irradiated at a distance of $20 \mathrm{~cm}$ away from the lamps. The cells were allowed to rest for $24 \mathrm{~h}$ and were then stained with Trypan Blue and counted utilizing a hemocytometer (Neubauer, Corning, the Netherlands) and an Optical Microscope (OLYMPUS IM, Olympus Deutschland GmbH, Hamburg, Germany) (20). Measurements were taken until $96 \mathrm{~h}$ after illumination and the experimental procedure was repeated at least three times in triplicate.

Cell-viability analysis (MTT assay). 3-(4,5-dimethylthiazol-2-yl)2,5-diphenyl-tetrazolium bromide (MTT) colorimetric assay Thiazolyl Blue Tetrazolium Bromide, M5655, Sigma-Aldrich, Darmstadt, Germany) was employed for the estimation of cell viability. Based on the functional principle of the MTT Assay and considering that the highest the number of viable cells, the highest the level of the formazan products, and consequently the highest the optical density value (21), the quantitation of cell viability, was achieved through the use of a multi-well scanning spectrophotometer (enzyme-linked immunosorbent assay reader). The optical density was measured at $570 \mathrm{~nm}$ and also at $650 \mathrm{~nm}$, for normalization against the background (22).

For the experimental needs of the MTT assay, MCF-7 and MDAMB-231 cells ( 10.000 cells/well) were cultured in 96-well plates. Increasing concentrations of the $\mathrm{Ag} / \mathrm{TiO}_{2} \mathrm{NPs}$ were added to the appropriate samples, $24 \mathrm{~h}$ after plating. Afterwards, the samples were irradiated using UV-A light for $10 \mathrm{~min}$, and allowed to rest for $48 \mathrm{~h}$.

According to the protocol that it has already described in a previous study of Lagopati et al. (7), the optical density was measured and the percentage of viability was estimated compared to untreated cells. The experiment was repeated five times in quadruplicate with similar results.

Western blotting. Western blotting experiments were performed to investigate the effect of the $\mathrm{Ag} / \mathrm{TiO}_{2} \mathrm{NPs}$ on caspase-mediated poly(adenosine diphosphate ribose) polymerase (PARP) cleavage, as an indication of selective cell apoptosis. A protocol that was previously described in the study of Lagopati et al. (6) was employed for cell lysis and protein quantitation. Membranes were probed with anti-PARP (9542; Cell Signaling Technology, Bioline Scientific, Athens, Greece), anti-Bcl-2 (sc-7382), anti-Bcl-xL (sc8392), anti-Bax (sc-7480), and anti-Bad (sc-9292) (Santa Cruz Biotechnology, Dallas, TX, USA) antibodies. An enhanced chemiluminescence detection system (Life Technologies, Thermo Scientific, Paisley, UK) was used for the protein detection, after incubation with horseradish peroxidase-conjugated secondary antibodies (GE Healthcare, Life Sciences, Amersham, Little Chalfont, Buckinghamshire, UK). The blots were stripped (Merck Millipore ReBlot Plus Kit and Reagents, Thermo Scientific) and reprobed with anti- $\beta$-tubulin (ab179511) monoclonal antibodies (Abcam, Cambridge, UK). Three independent experiments were implemented. 

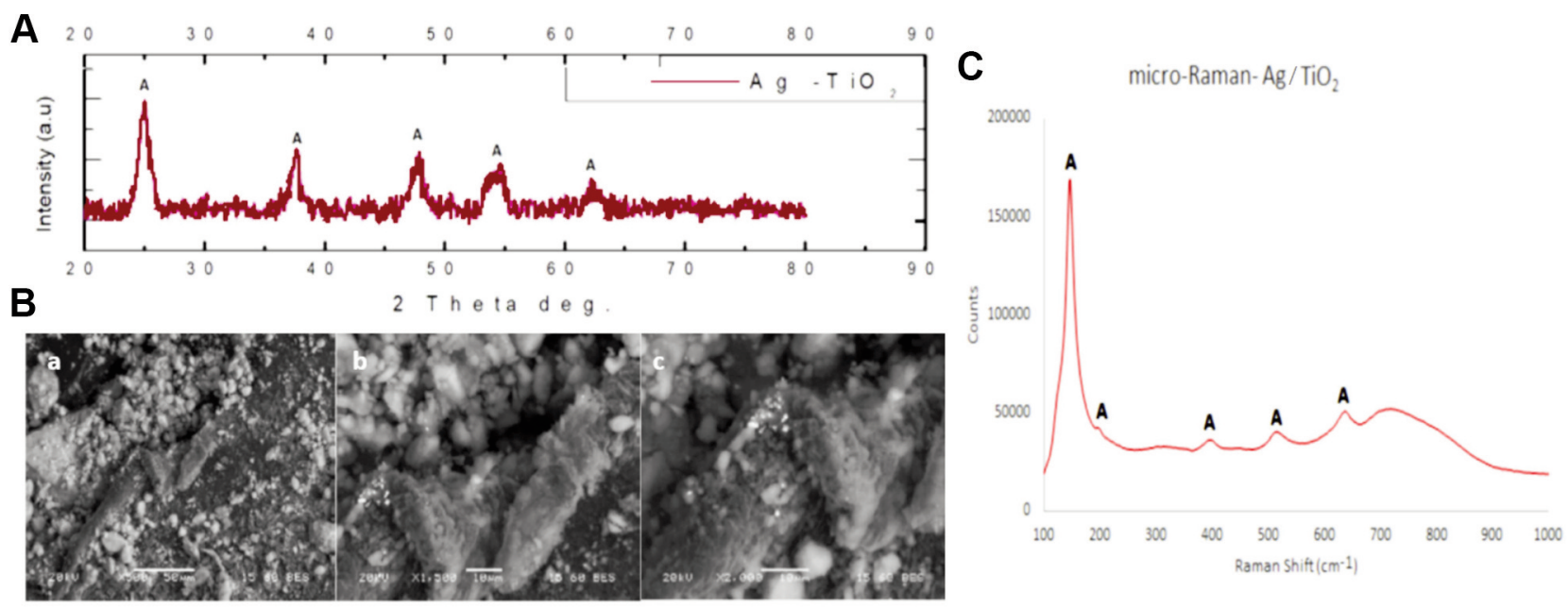

Figure 1. (A) X-ray diffraction patterns (XRD) of $\mathrm{Ag} / \mathrm{TiO} \mathrm{O}_{2} \mathrm{NPs}$ (silver-modified $\mathrm{TiO}_{2}$ nanoparticles). Anatase (A) is the dominant crystal phase of $\mathrm{Ag} / \mathrm{TiO}_{2}$, with the highest intensity diffraction peak of anatase being at $(2 \theta)=25.35^{\circ}$ (2-theta angle), corresponding to (1 01$)$ crystal plain. All the other detected peaks of A which are spotted are in accordance with the ICDD File No 03-065-5714. (B) FEG-SEM (Field emission gun scanning electron microscope) images of $\mathrm{Ag} / \mathrm{TiO}_{2} \mathrm{NPs}$ at $\times 500(\mathrm{a}), \times 1,500(\mathrm{~b})$ and $\times 2,000$ magnification $(\mathrm{c})$. (C) Raman spectrum of Ag/TiO $\mathrm{N}_{2} \mathrm{NPs}$. The spectrum identifies the formation of single anatase nano-crystalline phase, as all the peaks corresponding to the Raman fundamental modes of pure anatase crystal phase are located at 143 [Eg(1)], 197 [Eg(2)], 395 [B1 g(1)], $514(\mathrm{Alg})$, and $640[\mathrm{Eg}(3)] \mathrm{cm}^{-1}$.

DNA-laddering assay. DNA was isolated from each sample and separated by agarose gel electrophoresis, according to the previously described protocol at Lagopati et al. (6). Images of intact and/or laddered DNA were obtained to certify the effect of the $\mathrm{Ag} / \mathrm{TiO}_{2}$ NPs on apoptotic cell death.

$3 D$ organotypic model development. Airway fibroblasts were embedded in type I collagen, allowing contraction of the gel mimicking the underlying submucosa. Positively selected HBECCDC6 Tet-ON (normal human bronchial epithelial) cells were seeded on top of the contracted layer and upon attachment of HBECs on the underlying stroma, the organotypic culture was submerged into the appropriate medium and then lifted to an air-liquid interface, while cell growth was performed at $37^{\circ} \mathrm{C}$ with $5 \% \mathrm{CO}_{2}$. Matrigels were collected, formalin fixed, and paraffin embedded (23).

Statistical analysis. Values in each experiment are presented as means \pm standard deviation and statistically significant differences between the values of the samples were evaluated by one-way analysis of variance (ANOVA) as well as the nonparametric KruskalWallis method using SPSS (IBM Corporation, Armonk, NY, USA); $p<0.05$ value was considered as statistically significant. We initially chose ANOVA since it allows the total variance to be broken down into 2 parts: the variation within each sample and the variation between the groups. Thus, it is the best choice for cross checking all treatment conditions (control, UV-A, $\mathrm{Ag} / \mathrm{TiO}_{2}$, photoexcited $\mathrm{Ag} / \mathrm{TiO}_{2}$, cis-platin) (24). However, we additionally utilized the nonparametric Kruskal-Wallis test (25), since the number of our measurements did not allow us to verify whether the values follow a normal distribution or not. The results that were obtained from the two methods were similar. Moreover, the Bonferroni method was employed as a posthoc tool to specify the pairs of analyzed data that are statistically significantly different (26).

\section{Results}

$\mathrm{Ag} / \mathrm{TiO}_{2} \mathrm{NPs}$ Characterization. The crystallinity of the $\mathrm{Ag} / \mathrm{TiO}_{2}$ NPs was examined through XRD. Figure 1A depicts the recorded X-Ray diffraction diagram. Anatase (A) was the dominant crystal phase of $\mathrm{TiO}_{2}$ that was detected, with the highest diffraction peak intensity being at $2 \theta=25.35^{\circ}$, which corresponds to the anatase (101) crystal phase. The rest of the detected peaks of anatase that were spotted were found in accordance with the ICDD File No 03065-5714. The average crystallite size of the $\mathrm{TiO}_{2}$ powders can be estimated through Scherrer's equation (Equation 1):

$$
d=\frac{0.89 \lambda}{\beta \cos \theta}
$$

where $\mathrm{d}$ goes for the average crystalline size, 0.89 corresponds to the Scherrer's constant, $\lambda$ goes for the X-ray wavelength, $\theta$ is the diffraction angle and $\beta$ stands for the FWHM (fullwidth-half-maximum). Using the main peak of anatase (101) at $2 \theta=25.35^{\circ}(27)$, the average crystallite size of the Ag/doped $\mathrm{TiO}_{2}$ NPs was estimated to be approximately $17 \mathrm{~nm}$.

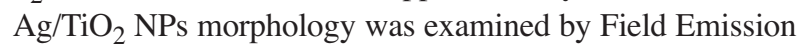
Scanning Electron Microscopy (FEG-SEM). Selected images are shown in Figure $1 \mathrm{~B}$. It seems that the tested $\mathrm{Ag} / \mathrm{TiO}_{2} \mathrm{NPs}$ consist of grains in the range of nanometers and there is homogeneity. These data are in agreement with the aforementioned XRD results.

Figure $1 \mathrm{C}$ presents the Raman spectrum of the $\mathrm{Ag} / \mathrm{TiO}_{2}$ NPs, identifying the formation of single anatase nano- 

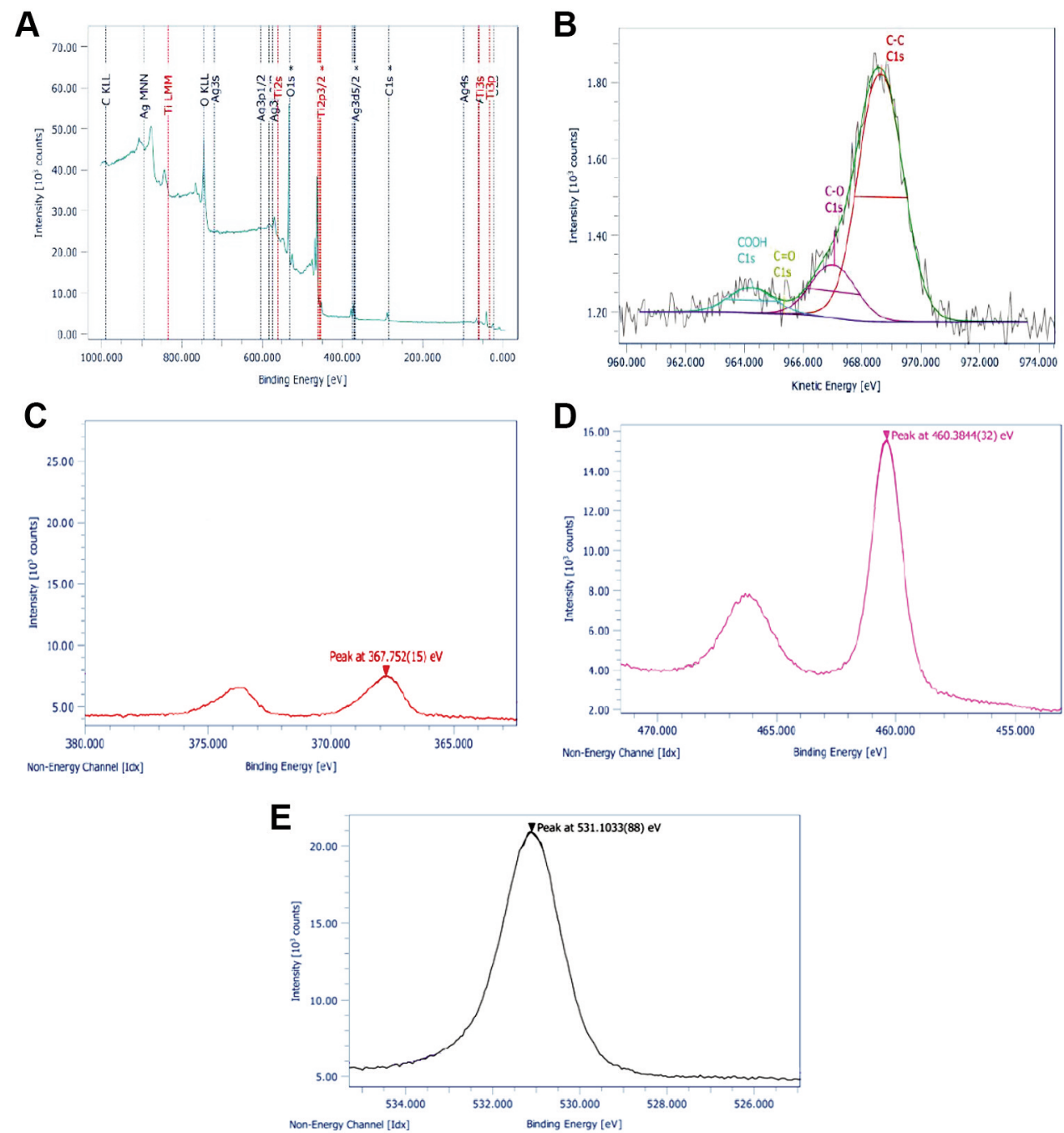

Figure 2. (A) Wide survey with high resolution XPS (X-ray photoelectron spectroscopy) spectra of $\mathrm{Ag} / \mathrm{TiO} \mathrm{O}_{2} \mathrm{NPs}$ (silver-modified TiO 2 nanoparticles) for (B) C1s, (C) Ag3d, (D) Ti2p and (E) O1s.

crystalline phase. This finding was obtained through the observation of all the peaks which correspond to the Raman fundamental modes of pure anatase crystal phase, located at $143[\operatorname{Eg}(1)], 197[\operatorname{Eg}(2)], 395[\mathrm{~B} 1 \mathrm{~g}(1)], 514(\mathrm{~A} 1 \mathrm{~g})$, and 640 $[\operatorname{Eg}(3)] \mathrm{cm}-1$. This result indicates the stabilization effect for the anatase phase as well as the inhibition of the anatasebrookite-rutile phase transformation, which was related to the silver treatment. These findings are in accordance with the relevant literature for Raman analysis (28).

XPS analysis was also performed in order to examine the elemental composition and the superficial chemistry of the $\mathrm{Ag} / \mathrm{TiO}_{2} \mathrm{NPs}$. All expected peaks according to the chemical synthesis protocol and design were detected. Thus, Ti2p $\left(\mathrm{TiO}_{2}\right.$ state), $\mathrm{O} 1 \mathrm{~s}\left(\mathrm{O}\right.$ in $\mathrm{TiO}_{2}$ state), $\mathrm{C} 1 \mathrm{~s}$ (hydrocarbon state) were obtained through XPS analysis. Figure 2A depicts the wide survey spectrum of $\mathrm{Ag} / \mathrm{TiO}_{2} \mathrm{NPs}$, detecting the peaks of Ti, O, $\mathrm{Ag}$ and $\mathrm{C}$. Figure 2B shows a detailed spectrum of $\mathrm{C} 1 \mathrm{~s}$ in high resolution, analyzed in $\mathrm{C}-\mathrm{C}$ bonds in suboxides/hydroxides $(\mathrm{C}$ $\mathrm{O})$, carbonyl $(\mathrm{C}=\mathrm{O})$ and carboxyl groups $(\mathrm{COOH})$. Carbonyls were not detected. X-Ray Induced Auger Electron Spectroscopy was employed for the identification of the silver. The modified Auger parameter was detected at $724.7 \mathrm{eVm}$ due to the silver oxide. The FWHM of $\mathrm{Ag} 3 \mathrm{~d}$ is wide enough, due to the presence of silver oxide. Figures 2C, 2D, 2E show the detailed spectra of $\mathrm{Ag} 3 \mathrm{~d}$, Ti2p and $\mathrm{O} 1 \mathrm{~s}$, respectively, in high resolution. Table I presents the compositional analysis, after the correction process for the sensitivity factors and the characteristics of the transit analyzer.

UV-Vis spectroscopy allows the estimation of the Eg of the $\mathrm{Ag} / \mathrm{TiO}_{2} \mathrm{NPs}$. The presence of the metal dopant on the 
Table I. Compositional analysis of $\mathrm{Ag} / \mathrm{TiO} \mathrm{O}_{2}$ (silver-modified $\mathrm{TiO}_{2}$ ).

\begin{tabular}{lccc}
\hline Name & Peak BE/eV & Compound & Atomic $\%$ \\
\hline $\mathrm{Ti} 2 \mathrm{p}_{3 / 2}$ & 460.3 & $\mathrm{TiO}_{2}$ & $25.76 \pm 0.14$ \\
$\mathrm{C} 1 \mathrm{~s}$ & 285.2 & Hydrocarbon & $16.61 \pm 0.22$ \\
$\mathrm{O} 1 \mathrm{~s}$ & 531.1 & $\mathrm{O}$ in $\mathrm{TiO}_{2}$ & $56.15 \pm 0.3$ \\
$\mathrm{Ag} 3 \mathrm{~d} 5 / 2$ & 367.7 & $\mathrm{AgO}$ & $1.48 \pm 0.01$ \\
\hline
\end{tabular}

surface of $\mathrm{TiO}_{2}$ NPs leads to a wide absorption bands, which is a characteristic of localized surface plasmon resonance (LSPR) absorption phenomenon. This is common in cases of metal-structures like silver and silver coated $\mathrm{TiO}_{2} \mathrm{NPs}$, according to literature (29). Visually, the $\mathrm{Ag} / \mathrm{TiO}_{2} \mathrm{NPs}$ are quite grey and not totally white compared to pure $\mathrm{TiO}_{2}$. This process of observed photochromism of the powders is associated with metal oxidation and reduction on the particles' surface. The position of the LSPR band center depends directly on the average particle size. Figure $3 \mathrm{~A}$ presents the absorbance spectra converted to the KubelkaMunk function, $\mathrm{F}(\mathrm{R})$, defined in equation 2 as (30):

$$
F(R)=\frac{a}{S}=\frac{(1-R)^{2}}{2 R}
$$

where $\alpha$ is the molar absorption coefficient, $\mathrm{S}$ the scattering factor and $\mathrm{R}$ is the absolute reflectance. This methodology is usually utilized for samples, exhibiting high absorbance or light scattering (30).

The band gap energy (Eg) was calculated by using Tauc's equation (Equation 3):

$$
(a h v)=A\left(h v-E_{g}\right)^{n}
$$

where $\mathrm{A}$ is a constant and $\mathrm{n}=2$ for indirect allowed transition (31).

In fact, by employing the Kubelka-Munk method extrapolating the linear portion of $(\mathrm{F}(\mathrm{R}) * \mathrm{hv}) 1 / 2 \mathrm{vs}$. hv, the bandgap was estimated at $3.1 \mathrm{eV}$ (Figure $3 \mathrm{~B}$ ), which is very close to the relevant Eg of the pure $\mathrm{TiO}_{2}$ (3-3.2 eV). Thus, $\mathrm{Ag} / \mathrm{TiO}_{2}$ has the ability to be photo-excited upon irradiation with UV light.

Finally, DLS was employed for the determination of the hydrodynamic radius zeta potential of $\mathrm{Ag} / \mathrm{TiO}_{2}$. The $\mathrm{pH}$ was 6.7-6.8. The hydrodynamic radius distribution as a function of intensity and the zeta potential are shown in Figure 4 and $\mathrm{B}$, respectively. It seems that the size distribution of the $\mathrm{Ag} / \mathrm{TiO}_{2}$ presents a maximum approximately at $145 \mathrm{~nm}$, with a coefficient of variation $(\mathrm{CV}) \sim 0,99 \%$. The zeta potential was found as $\mathrm{ZP}=(-14.8 \pm 8) \mathrm{mV}$, with a $\mathrm{CV} \sim 40 \%$, meaning that the dispersion was prone to form agglomerates. Thus, rigorus mixing and the use of ultrasounds to break the aggregations were employed, shrinking the size of the NPs, and optimizing their stability before their administration to cell cultures.

Biological Effect of $\mathrm{Ag} / \mathrm{TiO}_{2} \mathrm{NPS}$

Effect on cell proliferation. In order to investigate the effect of $\mathrm{Ag} / \mathrm{TiO}_{2} \mathrm{NPs}$ on cell proliferation, MCF-7 and MDA-MB231 cells were cultured ( 100,000 cells per well), with NPs dispersion concentration varying in the range of $0-0.8 \mathrm{mg} / \mathrm{ml}$. The cell number was estimated and recorded as a function of time to generate growth rates. As a positive control for the experiments, cells treated for $24 \mathrm{~h}$ with cisplatin $(0,8 \mathrm{mg} / \mathrm{ml})$ were used. Cells treated with UV-A light without $\mathrm{Ag} / \mathrm{TiO}_{2} \mathrm{NPs}$ were also utilized as an extra internal negative control, in order to ensure that the observed effect is not relevant to the irradiation itself. Therefore, we were able to exclude the case of the existence of thermal effects such as hyperthermia which would be a possible mechanism resulting in the inhibition of cell proliferation. It seems that there is no significant effect detected on cell proliferation for the MCF-7 cells, (Figure 5A). Upon irradiation with UV light there was also no significant effect on cell proliferation (Figure 5B). However, cell proliferation of the MDA-MB-231 cells, gradually inhibited in the presence of photoexcited $\mathrm{Ag} / \mathrm{TiO}_{2} \mathrm{NPs}$. A slight decrease was also observed in the presence of $0,8 \mathrm{mg} / \mathrm{ml}$ $\mathrm{Ag} / \mathrm{TiO}_{2}$ even without irradiation (Figure 5C). The highly malignant MDA-MB-231 cancer cells are proven o be more susceptible to the inhibition of cell proliferation or to cell death, exposed to photoexcited $\mathrm{Ag} / \mathrm{TiO}_{2} \mathrm{NPs}$ (Figure 5D), compared to MCF-7 cells, which are not metastatic. Herein, a cell-dependent toxicity was observed $(6,7)$ and this cell behavior could be explained if we consider the different nature of the two cell lines. Moreover, the membrane receptors could be different and consequently, they interact with the NPs in a different way, leading to a different biological effect (32).

Cell-viability analysis (MTT assay). The MTT colorimetric assay was employed to estimate the cytotoxic effects of $\mathrm{Ag} / \mathrm{TiO}_{2} \mathrm{NPs}$ on the viability of both cell lines. Hence, MDA-MB-231 and MCF-7 cells ( 10,000 cells per well) were incubated, with increasing concentrations of the NPs for $48 \mathrm{~h}$. The estimation of the percentage of cell viability as a function of the photocatalyst concentration was achieved through the Equation 4:

$$
\text { Cell Viability }=\frac{O D_{\text {treated sample }}-O D_{\text {background }}}{O D_{\text {untreated sample }}-O D_{\text {background }}} \cdot 100 \%
$$

where O.D. is the Optical Density measured for each sample. A gradual decrease in cell viability was observed, as the concentration of $\mathrm{Ag} / \mathrm{TiO}_{2} \mathrm{NPs}$ increased. More specifically, a concentration of $0,8 \mathrm{mg} / \mathrm{ml} \mathrm{Ag} / \mathrm{TiO}_{2}$ reduced MDA-MB-231 

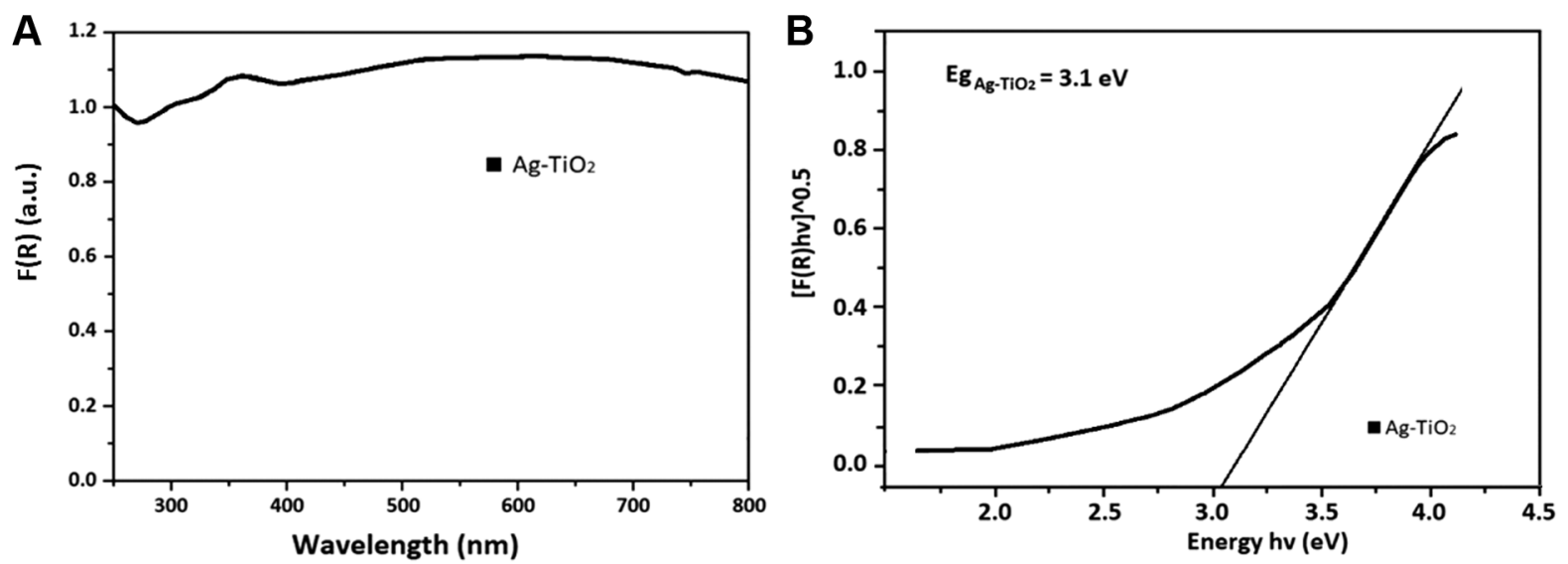

Figure 3. (A) Variation of $F(R)$ reflectance vs. wavelength for $\mathrm{Ag} / \mathrm{TiO} \mathrm{O}_{2} \mathrm{NPS}$ (silver-modified $\mathrm{TiO}_{2}$ nanoparticles) and (B) Optical band gap energy of $\mathrm{Ag} / \mathrm{TiO}_{2}$.
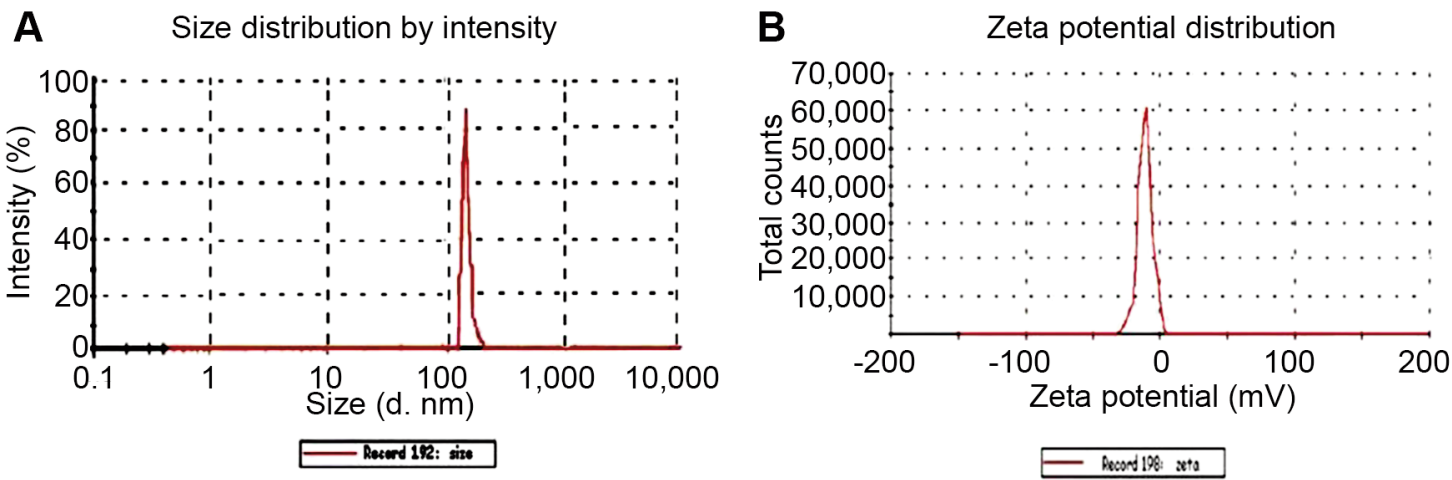

Figure 4. Dynamic light scattering (DLS) results. Distribution of the (A) hydrodynamic diameter (d, or $2 \mathrm{Rh})$ and $(\mathrm{B})$ zeta potential of the Ag/TiO 2 NPs (silver-modified $\mathrm{TiO}_{2}$ nanoparticles).

cell viability by $20 \%$, while the $\mathrm{MCF}-7$ cells were not significantly affected (Figure 6A). The cytotoxic effect was more significant upon UV irradiation. Photo-activated $\mathrm{Ag} / \mathrm{TiO}{ }_{2}$ reduced $40 \%$ the MDA-MB-231 cell population, while the same dose did not affect MCF-7 cells (Figure 6B). These series of experiments also showed a selective cytotoxicity of $\mathrm{Ag} / \mathrm{TiO}_{2}$. Possibly, the composition of the cell membrane proteins is different in each cell line and consequently the interactions between those proteins and $\mathrm{Ag} / \mathrm{TiO}_{2} \mathrm{NPs}$ are different in each case. This hypothesis could explain why the MCF-7 cells were not affected at all. It is also well established that stem cell characteristics are demonstrated in the the triple negative MDA-MB-231 cells, like high expression of cancer stem cells (SCCs) markers CD $44^{+} / \mathrm{CD} 24^{\text {low/- }}$ and high activity of aldehyde dehydrogenase (ALDH). These features are associated with stem cell self-protection (33). The presence of the xenobiotic transporter (BCRP) on MCF-7 cells can also explain their resistance in this treatment, since BCRP is considered to contribute to multi-drug resistance (34).

Apoptosis activation upon $\mathrm{Ag} / \mathrm{TiO}_{2}$ or photo-activated $\mathrm{Ag} / \mathrm{TiO} \mathrm{O}_{2}$ treatment. It is well known that cell apoptosis is characterized by various morphological, biochemical and functional changes that are mediated by the activation of caspases. One of the main cleavage targets of activated caspases is PARP $(113 \mathrm{kDa})$. PARP plays an important role in DNA repair, responding to an exposure to stress stimuli (35). PARP cleavage leads to an impaired enzymatic DNA-repair potential. In this regard, PARP cleavage can provide a reliable marker of cells that undergo programmed cell death $(36,37)$.

Western blot analysis was employed for the examination of PARP cleavage in both MCF-7 and MDA-MB-231 cells that treated with $\mathrm{Ag} / \mathrm{TiO}_{2}$ or photo-activated $\mathrm{Ag} / \mathrm{TiO}{ }_{2}$. Furthermore, cell lysates from samples that had been treated 
A

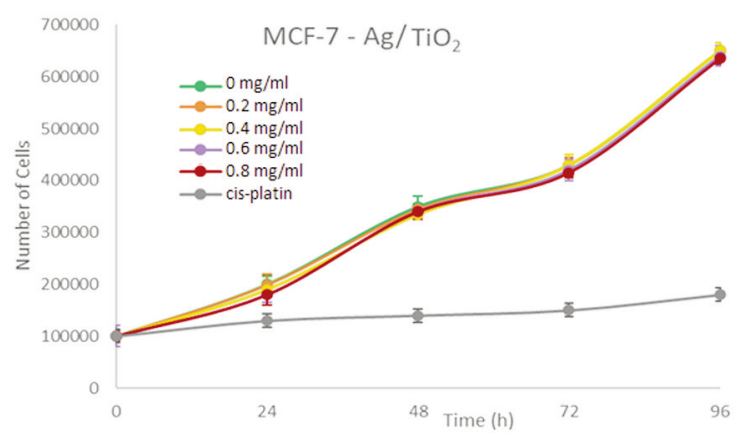

C

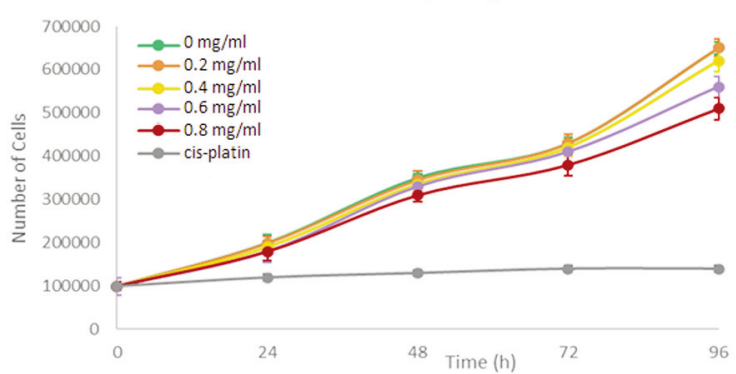

B

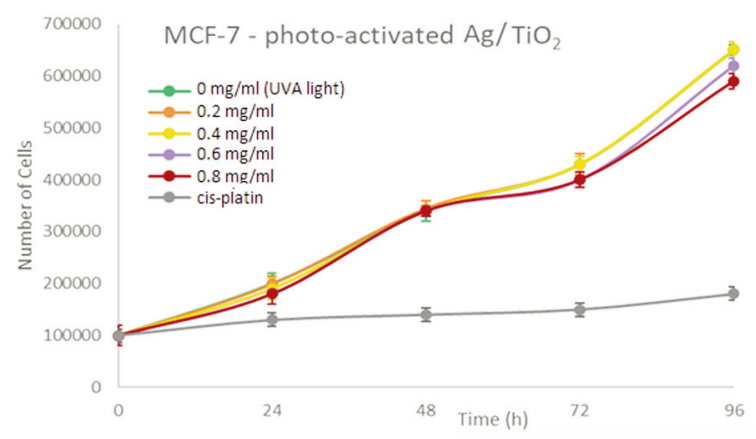

D

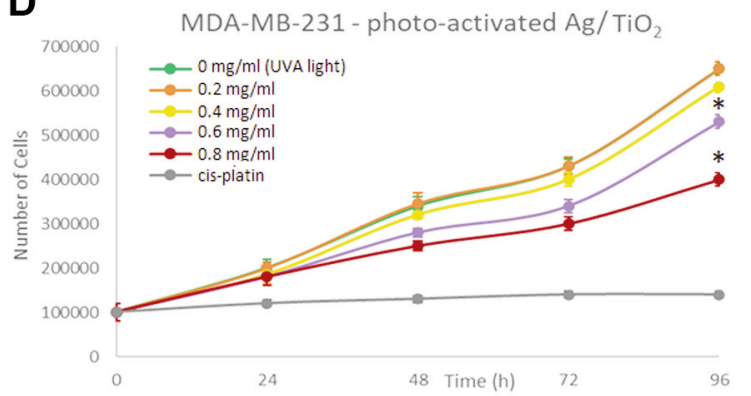

Figure 5. Effect of $\mathrm{Ag} / \mathrm{TiO}_{2} \mathrm{NPs}$ (silver-modified TiO $\mathrm{O}_{2}$ nanoparticles) on (A) MCF-7 (low metastatic potential) and (B) MDA-MB-231 (human breast adenocarcinoma, highly invasive) breast cancer epithelial cell proliferation. Effect of photoexcited $\mathrm{Ag} / \mathrm{TiO} \mathrm{O}_{2} \mathrm{NPs}$ on the proliferation of (C) MCF7 and (D) MDA-MB-231 breast cancer epithelial cells. Untreated cells were used as a negative control. Moreover, cells treated with UV-A light without $\mathrm{TiO}_{2}$ were used as an extra negative control. As a positive control, cells treated for $24 \mathrm{~h}$ with cis-platin $(0.8 \mathrm{mg} / \mathrm{ml})$ were used. $* p<0.05 \mathrm{vs}$. negative control (untreated) cells, based on the Kruskal-Wallis test. Data represent the mean \pm standard deviation from five independent experiments.

A

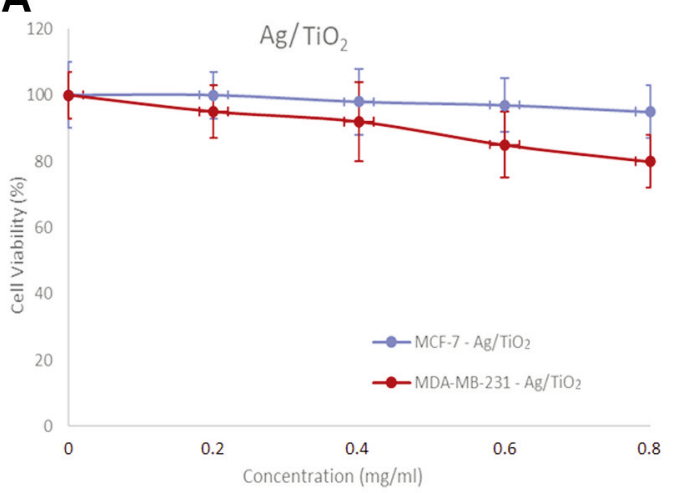

B

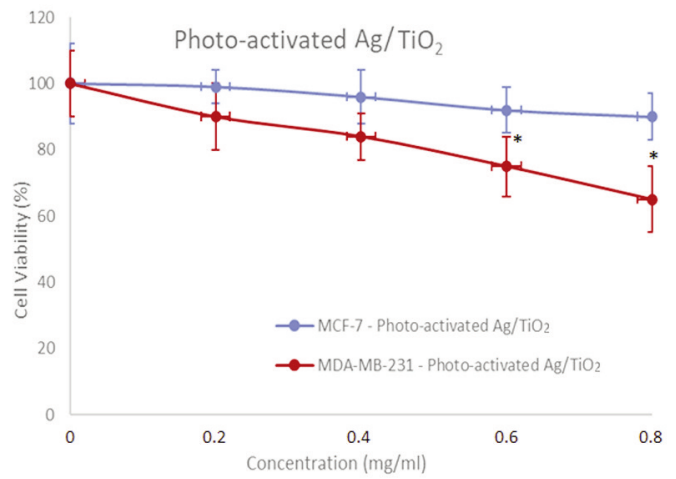

Figure 6. Effect of (A) $\mathrm{Ag} / \mathrm{TiO}_{2} \mathrm{NPs}$ (silver-modified $\mathrm{TiO}_{2}$ nanoparticles) and (B) Photo-excited Ag/TiO $\mathrm{N}_{2} \mathrm{NPs}$ on the viability of MCF-7 (low metastatic potential) and MDA-MB-231 (human breast adenocarcinoma, highly invasive) breast cancer epithelial cells. * $p<0.05 v s$. negative control, based on the Kruskal-Wallis test. MTT assay was employed to determine cell viability. Data represent means \pm standard deviation from five independent experiments.

for $24 \mathrm{~h}$ with cisplatin $(0.8 \mathrm{mg} / \mathrm{ml})$ were used as a positive control for our experiment, inducing PARP cleavage.

Representative blots of uncleaved and cleaved PARP on both the cell lines are depicted in Figure 7. It is quite clear that PARP cleavage was remarkably increased in MDA-MB231 cells treated with $\mathrm{Ag} / \mathrm{TiO}_{2}$ and, even more significantly, in those treated with photo-excited $\mathrm{Ag} / \mathrm{TiO}_{2}$ with UV-A, when comparing the obtained results with the untreated cells. 
A
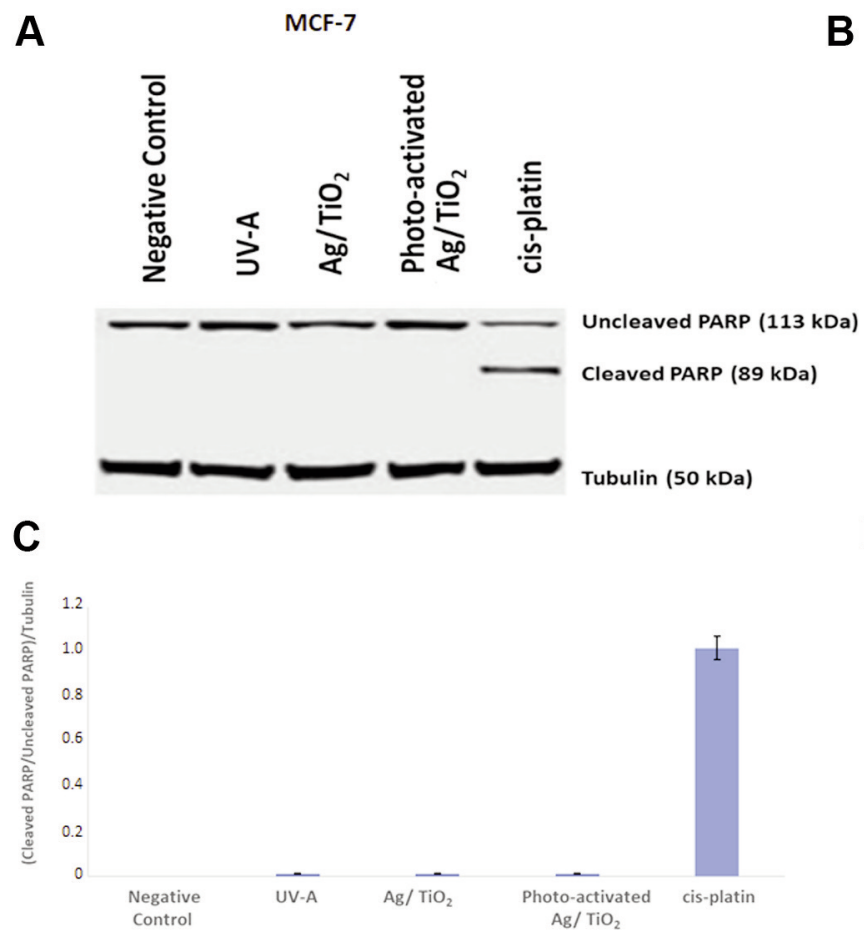

B

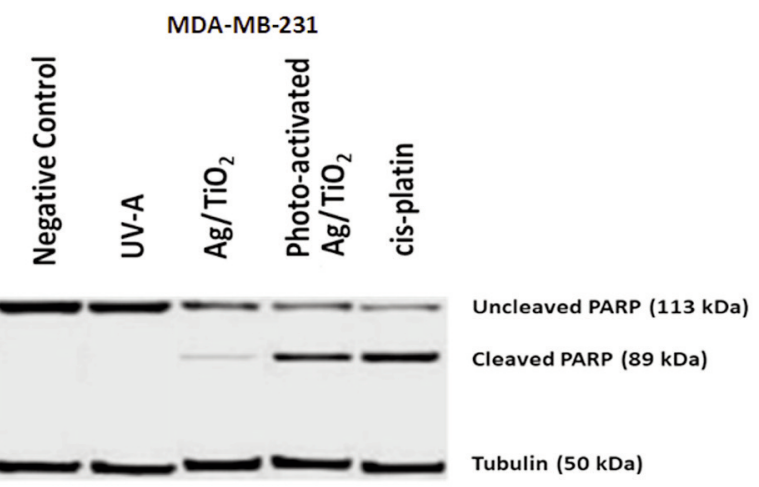

D

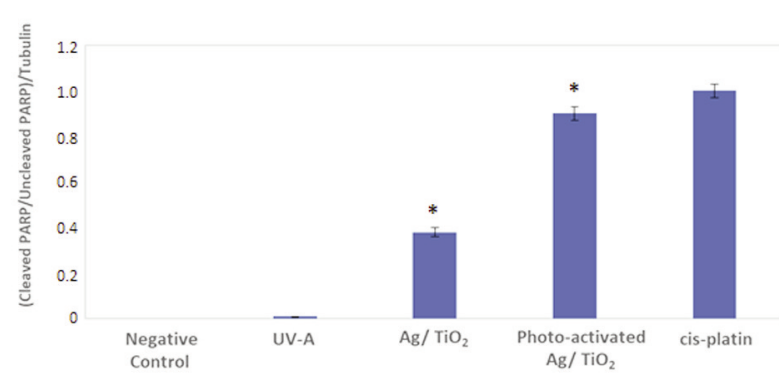

Figure 7. Ag/TiO $\mathrm{NPs}_{2}$ (silver-modified $\mathrm{TiO}_{2}$ nanoparticles) and photo-activated Ag/TiO $2 \mathrm{NPs}$ induce PARP cleavage. Representative immunoblots of cleaved and uncleaved PARP of MCF-7 (low metastatic potential) cells (A and C) and MDA-MB-231 (human breast adenocarcinoma, highly invasive) cells ( $B$ and $D)$. Blots were probed with anti-tubulin antibody, to ensure equal protein levels in each sample. Quantification of cleaved/uncleaved PARP [poly(adenosine diphosphate ribose) polymerase] to tubulin levels for * $p<0.05$ was held, compared to the relevant ratio of untreated cells and based on the Kruskal-Wallis test. Cells treated with cisplatin $(0.8 \mathrm{mg} / \mathrm{ml})$ for $24 \mathrm{~h}$ were also used as a positive control for the induction of PARP cleavage. Data represent means standard deviation from three independent experiments.

These findings show that $\mathrm{Ag} / \mathrm{TiO}_{2}$ has the potential to induce apoptosis in MDA-MB-231 cells (Figure 7B and D). We did not detect PARP cleavage in MCF-7 cells, following the same procedure (Figure $7 \mathrm{~A}$ and $\mathrm{C}$ ).

The Bcl-2 family of proteins consists of a number of evolutionarily conserved members, playing crucial roles in cell apoptosis regulation, either promoting or inhibiting the cytochrome $\mathrm{C}$ release into the cytosol. This fact consequently triggers caspase- 9 and caspase- 3 activation and leads to apoptosis. More specifically Bcl-2 family proteins can regulate apoptosis by controlling mitochondrial outer membrane permeabilization (MOMP), a pivotal step in the apoptosis intrinsic pathway. Hence, the expression of the antiapoptotic factors Bcl-2 and Bcl-xL, as well as the expression of the proapoptotic factors Bax, and Bad was also examined to further clarify the apoptotic mechanism. Cells were treated with photoexcited $\mathrm{Ag} / \mathrm{TiO}_{2}$ and cell lysates were immunoblotted and probed with anti-Bcl-2, anti-Bcl-xL, anti-Bax, and anti-Bad antibodies. Cells treated for $24 \mathrm{~h}$ with cisplatin $(0,8 \mathrm{mg} / \mathrm{ml})$ were used as a positive control for apoptosis induction.

Representative immunoblots blots of Bax, Bcl-2, Bad and Bcl-xL expression, obtained from in both cell lines are presented in Figure 8. $\mathrm{Ag} / \mathrm{TiO}_{2}$ and more significantly photoexcited $\mathrm{Ag} / \mathrm{TiO}_{2} \mathrm{NPs}$ led to an increase in Bax expression in MDA-MB-231 (Figure 9B and D), when compared to untreated cells. This finding is in agreement with the PARP cleavage that was found in the corresponding samples (Figure 7B and D). Moreover, a decrease in Bcl-2 expression was noticed in the same samples (Figure 9B and D). Under the same conditions, no significant effect was detected in MCF-7 cells in the expression of all the examined proteins (Bcl-2, Bax, Bcl-xL, Bad).

DNA-laddering assay. DNA-laddering assay is a widely used method for separation of DNA fragments, depending on their size and charge $(38,39)$. Cellular DNA damage treated with $\mathrm{Ag} / \mathrm{TiO}_{2} \mathrm{NPs}_{\text {was }}$ investigated through this assay. As shown in Figure 10, DNA fragmentation was induced by photoexcited $\mathrm{Ag} / \mathrm{TiO} 2 \mathrm{NPs}$ and very slightly by $\mathrm{Ag} / \mathrm{TiO}_{2} \mathrm{NPs}$ in MDA-MB-231 cells, if we compare these samples with the untreated cells (Figure 10B). The motif of fragmentation was quite similar to the fragmentation we noticed in the sample treated with cis-platin $(0.8 \mathrm{mg} / \mathrm{ml})$ for $24 \mathrm{~h}$. Cells irradiated with UV-A exhibited no significant DNA fragmentation. 


\section{HBEC-CDC6 TET ON cells}

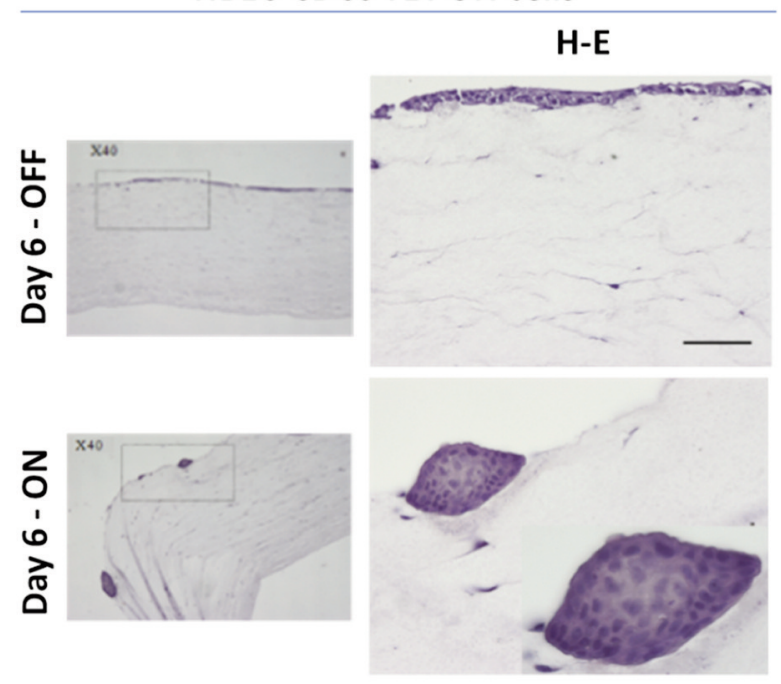

Figure 8. Representative images of the HBEC (normal human bronchial epithelial cells) -CDC6 Tet ON cellular model, grown in $3 D$ organotypic conditions and stained for $H-E$ (hematoxylin-eosin). The epithelial origin of HBECs is similar to various other cancer types, and in their un-induced state [(A) "OFF" state], they lack mutations found in cancer cells. This $3 D$ organotypic model allows the precise and reliable detection of amassing DNA alterations during CDC6-induced senescence $[(B)$ "ON" state $](23)$.

MCF-7 showed exactly what we have noticed in the previous experiments, i.e., the DNA-laddering pattern was not detected (Figure 10A). These results are in accordance with the PARP cleavage (Figure 7) and Bax and Bcl-2 expression (Figure 9), indicating apoptosis.

\section{Discussion}

Nanostructured $\mathrm{Ag} / \mathrm{TiO}_{2}$ was synthesized via the sol-gel method. Enhanced photocatalytic activity was observed, since the time needed for the efficient photo-activation was approximately $10 \mathrm{~min}$. Previous studies from our groups had shown that $\mathrm{TiO}_{2}$ induced apoptosis only after a 20-minirradiation with UV-A. Thus, silver modification allowed an optimization of the photocatalytic cytotoxicity that was controllably triggered in order to lead cancer cells to apoptosis. Full characterization, applying XRD, SEM, microRaman spectroscopy, UV-Vis spectroscopy and DLS verified the chemical modification $\mathrm{TiO}_{2}$ with silver as well as the characteristics of the produced nanomaterial. The cytotoxicity tests (growth rates and MTT assay) of $\mathrm{Ag} / \mathrm{TiO}_{2}$ NPs have indicated inhibition in cell proliferation of the MDA-MB-231 cells. The MCF-7 cells were resistant to the treatment, thus no significant effect on cell proliferation was observed. The results of Ahamed et al. are in accordance with our findings as they also indicated that $\mathrm{Ag} / \mathrm{TiO}_{2} \mathrm{NPs}$ did not cause cytotoxicity to human pulmonary cancer cells (A549) as well as MCF-7 cancer cells (40). They also found a cell-type selectivity, as they showed that $\mathrm{Ag} / \mathrm{TiO}_{2} \mathrm{NPs}$ had a significant effect on cell viability of human liver cancer (HepG2) cells. Our results are in contrast with the results of Murugan et al. who reported that $\mathrm{TiO}_{2} \mathrm{NPs}$ exhibit a dosedependent cytotoxicity in MCF-7 cells; however, the material they used is commercially available and non-modified. Moreover, the synthesis process is different and there was no photo-activation of the $\mathrm{TiO}_{2}$ photocatalyst, thus any comparison of the results would not be based in the same experimental conditions (41).

Hence, we have shown that a selectivity of the produced $\mathrm{Ag} / \mathrm{TiO}_{2}$ toward specific cancer cells occurs. There were also various studies indicating that $\mathrm{TiO}_{2} \mathrm{NPs}$ can affect some of the cellular functions, such as inhibition of cell proliferation and decrease in viability when tested in human skin-derived cells (42). Many hypotheses have been proposed regarding the mechanism through which $\mathrm{TiO}_{2}$ NPs potentially induce apoptosis or inhibit cell proliferation (32). $\mathrm{TiO}_{2}$ particlemediated cell toxicity could be interpreted, considering the interactions between cells and particles. However, to date, the specific interactions between $\mathrm{TiO}_{2} \mathrm{NPs}$ and membrane proteins are not totally understood. The surface characteristics of the $\mathrm{TiO}_{2}$ NPs seem to be pivotal factors in the bioactivity the NPs (43). In addition, we have already completed a preliminary series of experiments, testing $\mathrm{TiO}_{2}$ on Human Embryonic Kidney Cells (HEK293) and we have not detected any effect on cell viability. Among our aims is to investigate the biological effect of $\mathrm{Ag} / \mathrm{TiO}_{2}$ on various skin precancerous and melanoma cells, as we think that photo-activated $\mathrm{Ag} / \mathrm{TiO}_{2}$ might be used as a photosensitizer in an alternative photodynamic therapy, and thus superficial cancers like skin cancers would be the ideal biological system for this application.

The mechanism provoking this selectivity remains an unclarified field for further investigation. The possible mediated mechanism, that leads to the inhibition of cell proliferation is possibly through ROS generation, since previous studies also suggested that $\mathrm{TiO}_{2}$ NPs create a large amount of reactive oxygen species, that may potentially lead to DNA damage $(5,44-46)$. Various studies indicate that $\mathrm{TiO}_{2}$ NPs might induce apoptotic cell death in human non-small cell lung cancer cells (47), in human colon carcinoma cells (48) and others $(32,49,50)$. This study aimed to evaluate the apoptotic potential of $\mathrm{Ag} / \mathrm{TiO}_{2} \mathrm{NPs}$. For this reason, two different breast cancer epithelial cell lines: the highly malignant MDA-MB-231 and the low metastatic MCF-7 cells. Our results showed that the efficacy of $\mathrm{Ag} / \mathrm{TiO}{ }_{2} \mathrm{NPs}$ to induce apoptosis in MDA-MB-231 cells was significant. Herein MDA-MB-231 cancer cells seemed to be more susceptible to apoptosis, induced by photo-excited $\mathrm{Ag} / \mathrm{TiO}_{2}$ NPs, compared to the lowly metastatic MCF-7 cells. 
A

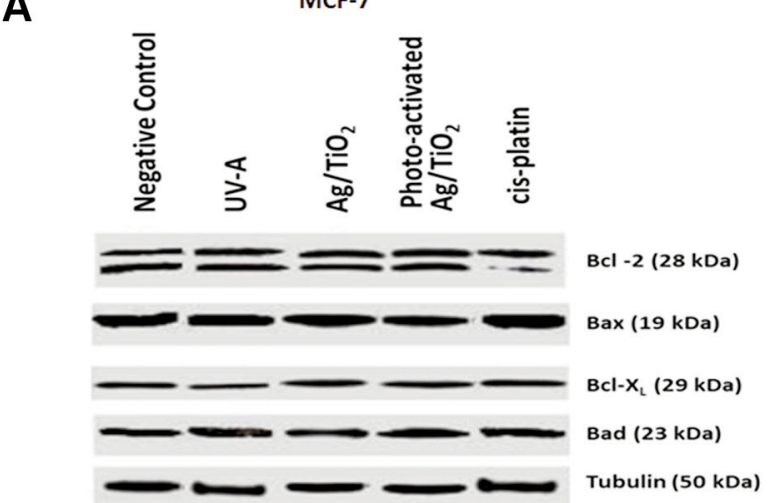

C

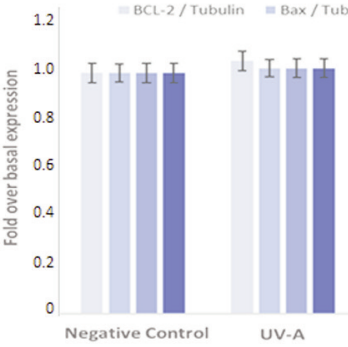

B

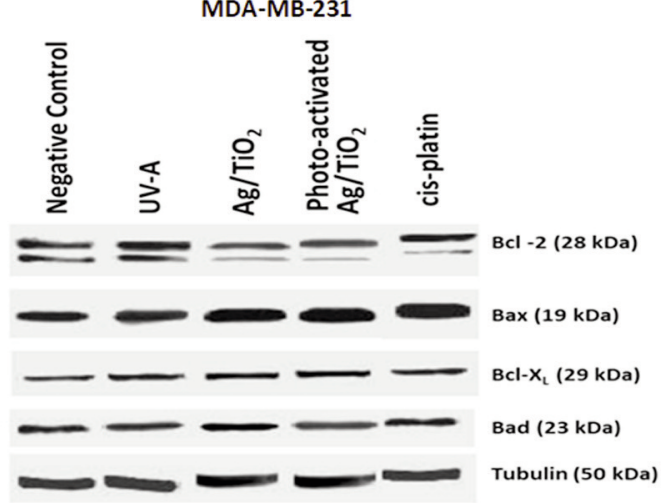

D

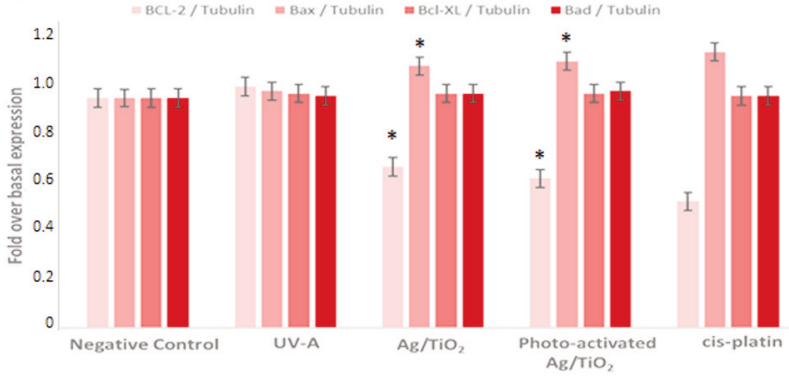

Figure 9. $\mathrm{Ag} / \mathrm{TiO}_{2} \mathrm{NPs}$ (silver-modified $\mathrm{TiO}_{2}$ nanoparticles) and photo-activated Ag/TiO $2 \mathrm{NPs}$ increased Bax expression and decreased Bcl-2 expression in MDA-MB-231 (human breast adenocarcinoma, highly invasive) cells. Representative immunoblots for Bcl-2, Bax, Bcl-xL and Bad expression in both cell lines are presented. Blots were also probed with anti-tubulin antibody for normalization. Densitometric quantification of Bcl-2/tubulin, Bax/tubulin, Bcl-xL/tubulin and Bad/tubulin as fold over basal rate (control cells) in (B and D) MDA-MB-231 cells and (A and C) MCF-7 (low metastatic potential) cells was performed, compared to the relevant ratios of untreated cells. Cells treated with cisplatin $(0.8 \mathrm{mg} / \mathrm{ml})$ for $24 \mathrm{~h}$ were also used as a positive control for the induction of Bcl-2 family of proteins deregulation. ${ }^{*} p<0.05 v s$. negative control, based on the Kruskal-Wallis test. Data represent means \pm standard deviation from three independent experiments.

A
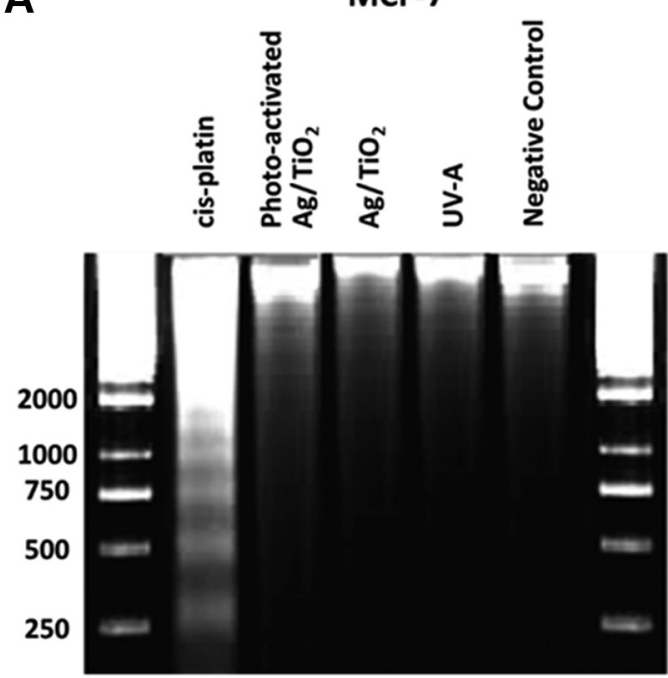

B MDA-MB-231

20002000

10001000

750750

500

250

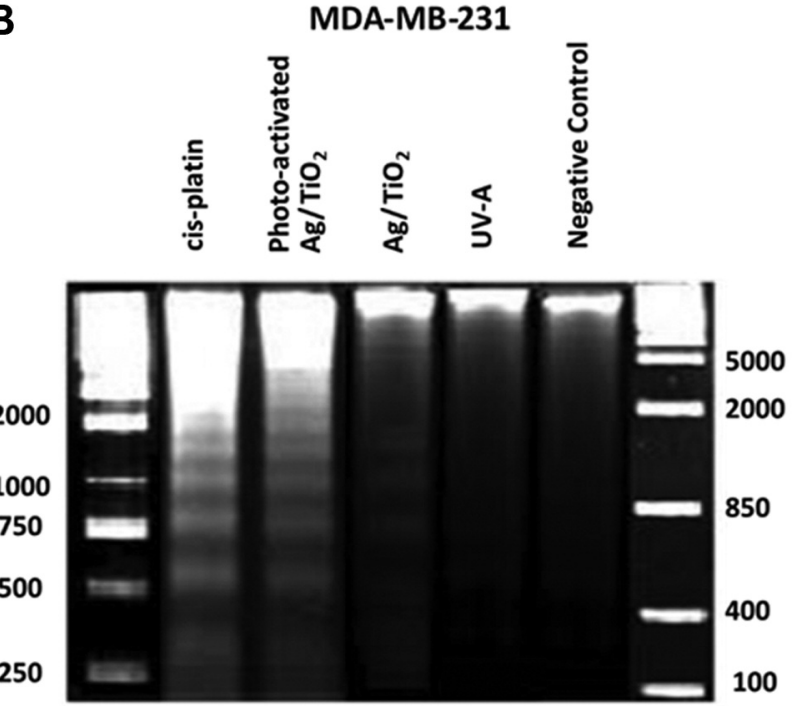

Figure 10. Photo-activated $\mathrm{Ag} / \mathrm{TiO}_{2} \mathrm{NPS}$ (silver-modified $\mathrm{TiO}_{2}$ nanoparticles) induced DNA laddering in the MDA-MB-231 (human breast adenocarcinoma, highly invasive) cell line. Representative patterns of DNA laddering in (A) MCF-7 (low metastatic potential) and (B) MDA-MB231 cells. Cells treated for $24 \mathrm{~h}$ with cisplatin $(0.8 \mathrm{mg} / \mathrm{ml})$ were used as positive controls for the induction of DNA laddering. 
Caspases play an important role in the apoptotic process, as their activation results in impaired cell function and programmed cell death (51). PARP is considered to be one of the main cleavage targets of caspases. During apoptosis, PARP is broken down into the inactive 89 and $24 \mathrm{kDa}$ fragments. The DNA-binding domain of cleaved PARP is localized in the small fragment and it can thus inhibit access by other repair enzymes. The role of the big fragment ( 89 $\mathrm{kDa}$ ) which is localized at the nucleoplasm during the apoptosis implementation, is to configure the activity of other proteins which are involved in apoptosis (e.g., p53) (52).

Bcl-2 family proteins, regulating the mitochondrial permeability, also play an important role in cell apoptosis. Various studies demonstrated that $\mathrm{TiO}_{2} \mathrm{NPs}$ have the ability to induce apoptosis and are detected with increased expression of the proapoptotic protein Bax (53). We also indicated that photoactivated $\mathrm{Ag} / \mathrm{TiO}_{2}$ can increase the Bax expression and decrease the Bcl-2 levels in MDA-MB-231 cell line. Since it is known that during the late stages of apoptosis DNA fragmentation takes place (54), we also tried to certify the prevalent mechanism, through the DNA laddering assay. We noticed that DNA fragmentation took place in MDA-MB-231 cells.

Among our main perspectives is to focus our effort on the effect of the modified $\mathrm{TiO}_{2}$ NPs on senescence, apart from apoptosis. We recently developed a cellular system based on normal human bronchial epithelial cells (HBECs) (23). HBEC system carries a CDC6-TetON overexpression cassette. The origin of HBECs is epithelia, like most common cancer types. Being at un-induced state ("OFF" state), HBECs are free from the mutation burden which is typically found in cancer cells. This permits precise and reliable detection of amassing DNA alterations during CDC6-induced senescence ("ON" state). It might be very promising to apply the modified $\mathrm{TiO}_{2}$ NPs on the 3Dorganotypic (Figure 8) cell culture conditions we have developed, which simulates a tissue related context, in addition to/as a substitute of in vivo studies.

Among our priorities is the optimization of the method by replacing ultraviolet with visible light. This is achievable through chemical modification with nitrogen, comodification with metals and non-metals or even triple modification. The coating of the produced materials with smart polymers, stimuli responsive, such as the IP network microgel pNipam-co-PAA have shown promising results (5) and are still under investigation. The coating can modify the oxidative behavior of NPs and enhance their bioactivity. Green synthesis of silver is also in our plans. Based on some preliminary experiments we suggest these methods that are eco-friendly and avoid toxic reagents (55).

Our promising findings and others derived from our previous intensive studies $(6,7)$, demonstrate that photoactivated $\mathrm{TiO}_{2} \mathrm{NPs}$ can be considered as an anticancer agent that could be applied locally, followed by light irradiation focused on the tumor area. The cancer cells might be selectively affected by a light beam, introduced through a fiber optic close to a tumor region in parallel with a $\mathrm{TiO}_{2} \mathrm{NPs}$ injection. The great advantage of this potential therapeutic scheme is that $\mathrm{TiO}_{2} \mathrm{NPs}$ are biocompatible and thus they do not affect healthy tissues, avoiding the undesirable side effects of the traditional anticancer approaches.

Such an alternative approach based on the utilization of NPs might be very favourable, taking into account that the multidrug-resistance of the tumor cells remains a major obstacle to the success of chemotherapy.

\section{Conclusion}

Nanostructured $\mathrm{Ag} /$ modified $\mathrm{TiO}_{2}$ was synthesized and characterized in order to be used for the investigation of their cytotoxicity on MCF-7 and MDA-MB-231 cells. An inhibition of cell proliferation on MDA-MB-231 cells was observed, while MCF-7 were unaffected. The precise molecular process involved in the preferential death of highly malignant cancer cells remains unclarified. Experiments for further investigation of this mechanism are in progress. However, our findings show that the $\mathrm{TiO}_{2}$ nanoparticle cytotoxicity can upregulate the proapoptotic Bax expression, downregulating the antiapoptotic Bcl-2 expression. DNA damage and caspase-mediated PARP cleavage are also associated phenomena, and this means that cell apoptosis is the prevalent mechanism of cytotoxicity.

The design and development of an alternative photodynamic cancer therapy that can activated upon visible light irradiation, in parallel with a drug delivery approach, using smart polymers that might allow the controllable release of the catalyst in the biological system, maintaining the photo-induced activity of the smart composite. Our promising results show that photoexcited $\mathrm{Ag} / \mathrm{TiO}_{2}$ might be considered as an anticancer agent. Hence, an alternative approach based on the use of nanomaterials might be very intriguing, if we consider that multidrug-resistance of tumor cells is a common major obstacle to the success of a chemotherapy in addition to undesirable side effects.

\section{Conflicts of Interest}

The Authors declare that there are no conflicts of interest.

\section{Authors' Contributions}

Conceptualization V.G.G. and E.A.P.; investigation N.L., D.V., M.A.; supervision, V.G.G., E.A.P., M.G., P.F., E.-P. C. T., A.K.; funding acquisition, V.G.G.; methodology, N.L., A.K., I.P., A.B., T.F., D.S.T., P.K.; resources V.G.G., E.A.P., P.F., E.-P. C. T.; formal analysis N.L., A.P., K.E.; visualization N.L., D.V., K.E.; statistical analysis N.L., S.K.; validation N.L., A.K., K.E.; writing the original draft N.L., D.V., A.P., M.A., K.E.; writing, reviewing and editing N.L., P.F., I.P., T.F., E.-P.C.T., M.G., A.K., E.A.P. and V.G.G. 


\section{Funding}

This study was financially supported by the National Public Investment Program of the Ministry of Development and Investment/General Secretariat for Research and Technology, in the framework of the of the Flagship Initiative to address SARS-CoV-2 (2020 EE01300001). It was also supported by the Welfare Foundation for Social \& Cultural Sciences, Athens, Greece (KIKPE); the Hellenic Foundation for Research and Innovation (HFRI) grants no. 775 and 3782 and NKUA-SARG grant 70/3/8916, by the kind donation of $\mathrm{H}$. Pappas and by IKY scholarships program (action "Reinforcement of Postdoctoral Researchers", (N. Lagopatischolarship for Postdoctoral Researchers-MIS5001552).

\section{Acknowledgements}

The Authors would like to acknowledge Labrini Sygellou for the XPS measurements performed in Surface Science Laboratory at the Foundation of Research and Technology Hellas, Institute of Chemical Engineering and High Temperature Chemical Processes (FORTH/ICE-HT) and Mrs. E. Kotsopoulou for her support.

\section{References}

1 Soares S, Sousa J, Pais A and Vitorino C: Nanomedicine: principles, properties, and regulatory issues. Front Chem 6: 360 2018. PMID: 30177965. DOI: 10.3389/fchem.2018.00360

2 Seery M, George R, Floris P and Pillai S: Silver doped titanium dioxide nanomaterials for enhanced visible light photocatalysis Journal of Photochemistry and Photobiology A: Chemistry 189(23): 258-263, 2019. DOI: 10.1016/j.jphotochem.2007.02.010

3 Lagopati N, Evangelou K, Falaras P, Tsilibary EC, Vasileiou PVS, Havaki S, Angelopoulou A, Pavlatou EA and Gorgoulis VG: Nanomedicine: Photo-activated nanostructured titanium dioxide, as a promising anticancer agent. Pharmacol Ther 222: 107795, 2020. PMID: 33358928. DOI: 10.1016/j.pharmthera.2020.107795

4 Vamvakas I, Lagopati N, Andreou M, Sotiropoulos M, Gatzis A, Limouris G, Antypas C and Lyra M: Patient specific computer automated dosimetry calculations during therapy with $111 \mathrm{In}$ Octreotide. European Journal of Radiography 1(4): 180-183, 2018. DOI: 10.1016/j.ejradi.2010.08.001

5 Galata E, Georgakopoulou EA, Kassalia ME, PapadopoulouFermeli $\mathrm{N}$ and Pavlatou EA: Development of smart composites based on doped- $\mathrm{TiO}_{2}$ nanoparticles with visible light anticancer properties. Materials (Basel) 12(16): 2589, 2019. PMID: 31416238. DOI: $10.3390 / \mathrm{ma} 12162589$

6 Lagopati N, Tsilibary EP, Falaras P, Papazafiri P, Pavlatou EA, Kotsopoulou E and Kitsiou P: Effect of nanostructured $\mathrm{TiO}_{2}$ crystal phase on photoinduced apoptosis of breast cancer epithelial cells. Int J Nanomedicine 9: 3219-3230, 2014. PMID: 25061298. DOI: 10.2147/IJN.S62972

7 Lagopati N, Kitsiou P, Kontos A, Venieratos P, Kotsopoulou E, Kontos A, Dionysiou D, Pispas S, Tsilibary E and Falaras P: Photo-induced treatment of breast epithelial cancer cells using nanostructured titanium dioxide solution. Journal of Photochemistry and Photobiology A: Chemistry 214(2-3): 215223, 2019. DOI: 10.1016/j.jphotochem.2010.06.031

8 Kim H, Jeon D, Oh S, Nam K, Son S, Gye M and Shin I: Titanium dioxide nanoparticles induce apoptosis by interfering with EGFR signaling in human breast cancer cells. Environmental Research 175: 117-123, 2019. PMID: 31112848. DOI: $10.1016 /$ j.envres.2019.05.001

9 Gorgoulis V, Adams PD, Alimonti A, Bennett DC, Bischof O, Bishop C, Campisi J, Collado M, Evangelou K, Ferbeyre G, Gil J, Hara E, Krizhanovsky V, Jurk D, Maier AB, Narita M, Niedernhofer L, Passos JF, Robbins PD, Schmitt CA, Sedivy J, Vougas K, von Zglinicki T, Zhou D, Serrano M and Demaria M: Cellular senescence: defining a path forward. Cell 179(4): 813827, 2019. PMID: 31675495. DOI: 10.1016/j.cell.2019.10.005

10 Muñoz-espín D: Nanocarriers targeting senescent cells. Translational Medicine of Aging 3: 1-5, 2020. DOI: 10.1016/j.tma.2019.01.001

11 Liao C, Li Y and Tjong SC: Visible-light active titanium dioxide nanomaterials with bactericidal properties. Nanomaterials (Basel) 10(1): 124, 2020. PMID: 31936581. DOI: 10.3390/ nano10010124

12 Barbouti A, Lagopati N, Veroutis D, Goulas V, Evangelou K, Kanavaros P, Gorgoulis VG and Galaris D: Implication of dietary iron-chelating bioactive compounds in molecular mechanisms of oxidative stress-induced cell ageing. Antioxidants (Basel) 10(3): 491, 2021. PMID: 33800975. DOI: 10.3390/antiox 10030491

$13 \mathrm{Fu}$ YS, Li J and Li J: Metal/semiconductor nanocomposites for photocatalysis: fundamentals, structures, applications and properties. Nanomaterials (Basel) 9(3): 359, 2019. PMID: 30836647. DOI: $10.3390 /$ nano9030359

14 Anaya-Esparza LM, Ruvalcaba-Gómez JM, Maytorena-Verdugo CI, González-Silva N, Romero-Toledo R, Aguilera-Aguirre S, Pérez-Larios A and Montalvo-González AE: Chitosan- $\mathrm{TiO}_{2}$ : A versatile hybrid composite. Materials (Basel) 13(4): 811, 2020. PMID: 32053948. DOI: 10.3390/ma13040811

15 Ilisz I and Dombi A: Investigation of the photodecomposition of phenol in near-UV-irradiated aqueous $\mathrm{TiO} 2$ suspensions. II. Effect of charge-trapping species on product distribution. Applied Catalysis A: General 180(1-2): 35-45, 2019. DOI: 10.1016/S0926-860X(98)00375-5

16 Etacheri V, Di valentin C, Schneider J, Bahnemann D and Pillai S: Visible-light activation of $\mathrm{TiO} 2$ photocatalysts: Advances in theory and experiments. Journal of Photochemistry and Photobiology C: Photochemistry Reviews 25: 1-29, 2019. DOI: 10.1016/j.jphotochemrev.2015.08.003

17 Chao H, Yun Y, Xingfang $\mathrm{H}$ and Larbot A: Effect of silver doping on the phase transformation and grain growth of sol-gel titania powder. Journal of the European Ceramic Society 23(9): 1457-1464, 2020. DOI: 10.1016/S0955-2219(02)00356-4

18 Nbelayim P, Kawamura G, Kian Tan W, Muto H and Matsuda A: Systematic characterization of the effect of $\mathrm{Ag} @ \mathrm{TiO}_{2}$ nanoparticles on the performance of plasmonic dye-sensitized solar cells. Sci Rep 7(1): 15690, 2017. PMID: 29146918. DOI: 10.1038/s41598-017-15541-z

19 Santos L, Machado W, França M, Borges K, Paniago R, Patrocinio A and Machado A: Structural characterization of Agdoped $\mathrm{TiO} 2$ with enhanced photocatalytic activity. RSC Advances 5(125): 103752-103759, 2017. DOI: 10.1039/ C5RA22647C

20 Piccinini F, Tesei A, Arienti C and Bevilacqua A: Cell counting and viability assessment of 2D and 3D cell cultures: Expected reliability of the trypan blue assay. Biological Procedures Online 19(1): 8, 2020. DOI: 10.1186/s12575-017-0056-3 
21 Mosmann T: Rapid colorimetric assay for cellular growth and survival: application to proliferation and cytotoxicity assays. J Immunol Methods 65(1-2): 55-63, 1983. PMID: 6606682. DOI: 10.1016/0022-1759(83)90303-4

22 Plumb JA: Cell sensitivity assays: the MTT assay. Methods Mol Med 88: 165-169, 2004. PMID: 14634227. DOI: 10.1385/159259-406-9:165

23 Komseli ES, Pateras IS, Krejsgaard T, Stawiski K, Rizou SV, Polyzos A, Roumelioti FM, Chiourea M, Mourkioti I, Paparouna E, Zampetidis CP, Gumeni S, Trougakos IP, Pefani DE, O'Neill E, Gagos S, Eliopoulos AG, Fendler W, Chowdhury D, Bartek J and Gorgoulis VG: A prototypical non-malignant epithelial model to study genome dynamics and concurrently monitor micro-RNAs and proteins in situ during oncogene-induced senescence. BMC Genomics 19(1): 37, 2018. PMID: 29321003. DOI: $10.1186 / \mathrm{s} 12864-017-4375-1$

24 Gelman A: Analysis of variance - why it is more important than ever. The Annals of Statistics 33(1): 1-53, 2021. DOI: 10.1214/009053604000001048

25 Acar E and Sun L: A generalized Kruskal-Wallis test incorporating group uncertainty with application to genetic association studies. Biometrics 69(2): 427-435, 2019. PMID: 23441822. DOI: $10.1111 /$ biom.12006

26 Lee $\mathrm{S}$ and Lee DK: What is the proper way to apply the multiple comparison test? Korean J Anesthesiol 71(5): 353-360, 2018. PMID: 30157585. DOI: 10.4097/kja.d.18.00242

27 Patterson A: The Scherrer formula for X-ray particle size determination. Physical Review 56(10): 978-982, 2017. DOI: 10.1103/PhysRev.56.978

$28 \mathrm{Li} \mathrm{Z,} \mathrm{Mi} \mathrm{L,} \mathrm{Wang} \mathrm{PN} \mathrm{and} \mathrm{Chen} \mathrm{JY:} \mathrm{Study} \mathrm{on} \mathrm{the} \mathrm{visible-light-}$ induced photokilling effect of nitrogen-doped TiO2 nanoparticles on cancer cells. Nanoscale Res Lett 6(1): 356, 2011. PMID: 21711880. DOI: 10.1186/1556-276X-6-356

29 Stathatos E, Lianos P, Falaras P and Siokou A: Photocatalytically deposited silver nanoparticles on mesoporous TiO2Films. Langmuir 16(5): 2398-2400, 2019. DOI: 10.1021/la981783t

30 López R and Gómez R: Band-gap energy estimation from diffuse reflectance measurements on sol-gel and commercial TiO2: a comparative study. Journal of Sol-Gel Science and Technology 61(1): 1-7, 2019. DOI: 10.1007/s10971-011-2582-9

31 Sanchez-martinez A, Ceballos-sanchez O, Koop-santa C, Lópezmena E, Orozco-guareño E and García-guaderrama M: N-doped $\mathrm{TiO} 2$ nanoparticles obtained by a facile coprecipitation method at low temperature. Ceramics International 44(5): 5273-5283, 2020. DOI: $10.1016 /$ j.ceramint.2017.12.140

32 Thevenot P, Cho J, Wavhal D, Timmons RB and Tang L: Surface chemistry influences cancer killing effect of $\mathrm{TiO} 2$ nanoparticles. Nanomedicine 4(3): 226-236, 2008. PMID: 18502186. DOI: 10.1016/j.nano.2008.04.001

33 Hero T, Bühler H, Kouam PN, Priesch-Grzeszowiak B, Lateit T and Adamietz IA: The triple-negative breast cancer cell line MDA-MB 231 is specifically inhibited by the ionophore salinomycin. Anticancer Res 39(6): 2821-2827, 2019. PMID: 31177119. DOI: 10.21873 /anticanres. 13410

34 Croker AK, Goodale D, Chu J, Postenka C, Hedley BD, Hess DA and Allan AL: High aldehyde dehydrogenase and expression of cancer stem cell markers selects for breast cancer cells with enhanced malignant and metastatic ability. J Cell Mol Med 13(8B): 2236-2252, 2009. PMID: 18681906. DOI: 10.1111/j.1582-4934.2008.00455.x
35 Satoh MS and Lindahl T: Role of poly(ADP-ribose) formation in DNA repair. Nature 356(6367): 356-358, 1992. PMID: 1549180. DOI: $10.1038 / 356356 \mathrm{a} 0$

36 Alvarez-Gonzalez R, Spring $\mathrm{H}$, Müller $\mathrm{M}$ and Bürkle A: Selective loss of poly(ADP-ribose) and the $85-\mathrm{kDa}$ fragment of poly(ADP-ribose) polymerase in nucleoli during alkylationinduced apoptosis of HeLa cells. J Biol Chem 274(45): 3212232126, 1999. PMID: 10542247. DOI: 10.1074/jbc.274.45.32122

37 Oliver FJ, de la Rubia G, Rolli V, Ruiz-Ruiz MC, de Murcia G and Murcia JM: Importance of poly(ADP-ribose) polymerase and its cleavage in apoptosis. Lesson from an uncleavable mutant. J Biol Chem 273(50): 33533-33539, 1998. PMID: 9837934. DOI: $10.1074 / \mathrm{jbc} .273 .50 .33533$

38 Satkauskas S, Bureau MF, Puc M, Mahfoudi A, Scherman D, Miklavcic D and Mir LM: Mechanisms of in vivo DNA electrotransfer: respective contributions of cell electropermeabilization and DNA electrophoresis. Mol Ther 5(2): 133-140, 2002. PMID: 11829520. DOI: $10.1006 / \mathrm{mthe} .2002 .0526$

39 Brody JR and Kern SE: History and principles of conductive media for standard DNA electrophoresis. Anal Biochem 333(1): 1-13, 2004. PMID: 15351274. DOI: 10.1016/j.ab.2004.05.054

40 Ahamed M, Khan MAM, Akhtar MJ, Alhadlaq HA and Alshamsan A: Ag-doping regulates the cytotoxicity of $\mathrm{TiO}_{2}$ nanoparticles via oxidative stress in human cancer cells. Sci Rep 7(1): 17662, 2017. PMID: 29247182. DOI: 10.1038/s41598-017-17559-9

41 Murugan K, Dinesh D, Kavithaa K, Paulpandi M, Ponraj T, Alsalhi MS, Devanesan S, Subramaniam J, Rajaganesh R, Wei H, Kumar S, Nicoletti $\mathrm{M}$ and Benelli G: Hydrothermal synthesis of titanium dioxide nanoparticles: mosquitocidal potential and anticancer activity on human breast cancer cells (MCF-7). Parasitol Res 115(3): 10851096, 2016. PMID: 26621285. DOI: 10.1007/s00436-015-4838-8

42 Kiss B, Bíró T, Czifra G, Tóth BI, Kertész Z, Szikszai Z, Kiss AZ, Juhász I, Zouboulis CC and Hunyadi J: Investigation of micronized titanium dioxide penetration in human skin xenografts and its effect on cellular functions of human skinderived cells. Exp Dermatol 17(8): 659-667, 2008. PMID: 18312389. DOI: $10.1111 / \mathrm{j} .1600-0625.2007 .00683 . x$

43 Huerta-García E, Zepeda-Quiroz I, Sánchez-Barrera H, ColínVal Z, Alfaro-Moreno E, Ramos-Godinez MDP and LópezMarure R: Internalization of titanium dioxide nanoparticles is cytotoxic for $\mathrm{H} 9 \mathrm{c} 2$ rat cardiomyoblasts. Molecules 23(8): 1955, 2018. PMID: 30082584. DOI: 10.3390/molecules23081955

44 Abdal Dayem A, Hossain MK, Lee SB, Kim K, Saha SK, Yang GM, Choi HY and Cho SG: The role of reactive oxygen species (ROS) in the biological activities of metallic nanoparticles. Int J Mol Sci 18(1): 120, 2017. PMID: 28075405. DOI: 10.3390/ijms 18010120

45 Yu Z, Li Q, Wang J, Yu Y, Wang Y, Zhou Q and Li P: Reactive oxygen species-related nanoparticle toxicity in the biomedical field. Nanoscale Res Lett 15(1): 115, 2020. PMID: 32436107. DOI: $10.1186 / \mathrm{s} 11671-020-03344-7$

46 Chibber S: Titanium dioxide (Tio2) nanoparticles induced ROS generation and its effect on cellular antioxidant defense in WRL68 cell. MOJ Bioequivalence \& Bioavailability 3(3): 70-74, 2019. DOI: $10.15406 /$ mojbb.2017.03.00036

47 Wang Y, Cui H, Zhou J, Li F, Wang J, Chen M and Liu Q: Cytotoxicity, DNA damage, and apoptosis induced by titanium dioxide nanoparticles in human non-small cell lung cancer A549 cells. Environ Sci Pollut Res Int 22(7): 5519-5530, 2015. PMID: 25339530. DOI: $10.1007 / \mathrm{s} 11356-014-3717-7$ 
48 De Angelis I, Barone F, Zijno A, Bizzarri L, Russo MT, Pozzi R, Franchini F, Giudetti G, Uboldi C, Ponti J, Rossi F and De Berardis B: Comparative study of $\mathrm{ZnO}$ and TiO $\square$ nanoparticles: physicochemical characterisation and toxicological effects on human colon carcinoma cells. Nanotoxicology 7(8): 1361-1372, 2013. PMID: 23078188. DOI: $10.3109 / 17435390.2012 .741724$

49 Warheit DB, Webb TR, Reed KL, Frerichs S and Sayes CM: Pulmonary toxicity study in rats with three forms of ultrafineTiO2 particles: differential responses related to surface properties. Toxicology 230(1): 90-104, 2007. PMID: 17196727. DOI: $10.1016 /$ j.tox.2006.11.002

50 Behnam MA, Emami F, Sobhani Z and Dehghanian AR: The application of titanium dioxide $\left(\mathrm{TiO}_{2}\right)$ nanoparticles in the photo-thermal therapy of melanoma cancer model. Iran J Basic Med Sci 21(11): 1133-1139, 2018. PMID: 30483386. DOI: 10.22038/IJBMS .2018.30284.7304

51 Elmore S: Apoptosis: a review of programmed cell death. Toxicol Pathol 35(4): 495-516, 2007. PMID: 17562483. DOI: $10.1080 / 01926230701320337$
52 Chaitanya GV, Steven AJ and Babu PP: PARP-1 cleavage fragments: signatures of cell-death proteases in neurodegeneration. Cell Commun Signal 8: 31, 2010. PMID: 21176168. DOI: $10.1186 / 1478-811 X-8-31$

53 Gross A and Katz SG: Non-apoptotic functions of BCL-2 family proteins. Cell Death Differ 24(8): 1348-1358, 2017. PMID: 28234359. DOI: $10.1038 / \mathrm{cdd} .2017 .22$

54 Lagopati N, Belogiannis K, Angelopoulou A, Papaspyropoulos $\mathrm{A}$ and Gorgoulis V: Non-canonical functions of the ARF tumor suppressor in development and tumorigenesis. Biomolecules 11(1): 86, 2021. PMID: 33445626. DOI: 10.3390/biom11010086

55 Lagopati N, Gatou MA, Tsoukleris DS and Pavlatou EA: Biogenic synthesis of silver nanoparticles with antimicrobial properties. Nanomed Nanotechnol 5(2): 000185, 2020. DOI: 10.23880/nnoa-16000185

Received April 12, 2021

Revised April 24, 2021

Accepted April 26, 2021 